\title{
Vepsäläisten lyhyiden pajojen metrinen malli ja sen toteutus
}

\section{Johdanto}

Tarkastelen vepsäläisten ehkä suosituimman laululajin, lyhyiden pajojen, metriikkaa. Hyvin usein lyhyitä pajoja, joskus vain pajoja, kutsutaan myös tšastuškoiksi, koska ne muistuttavat hyvin paljon toisiaan tai ovat useimpien ihmisten mielestä sama asia. ${ }^{1}$ Tšastuškat ovat olleet ja ovat vieläkin hyvin suosittu laulumuoto etenkin Pohjois-Venäjällä sekä venäläisten että myös samoilla alueilla asuvien vähemmistökansojen keskuudessa. Sisällöltään tšastuškat kertovat arkipäivän asioista ja yleensä teksteihin liittyy seksuaalinen lataus tai viesti toiselle sukupuolelle. Laulut ovatkin olleet perinteisesti nuorison leikki- ja rakkauslauluja. (Ks. Čistov 1976: 171, 203). ${ }^{2}$ Tšastuškojen käyttö (vepsäläisillä) ei kuitenkaan rajoitu vain rakkauslauluihin vaan niitä voidaan esittää hyvin erilaisissa tilanteissa: työlauluina, karhun karkotuslauluina, kosiolauluina tai häälauluina tai kun ollaan esimerkiksi pesemässä joen rannassa pyykkiä. ${ }^{3}$ Laulut esitetään yleensä tilanteeseen kuuluvalla tavalla, jolloin esimerkiksi tempo ja melodia saattavat muuttua sanojen ja rakenteen pysyessä samanlaisina. Esimerkiksi monet äänittämistäni työlaulu-tšastuškoista, ovat olleet tempoltaan huomattavasti hitaampia kuin esimerkiksi tanssin aikana esitettävät laulut. Voidaankin sanoa, että tšastuška-termi, myös silloin kun puhutaan venäläisestä tai vepsäläisestä tšastuškasta, on yleisnimitys monille niille lauluille tai laululajeille, jotka noudattavat tšastuškan rakennetta ja muotoa. ${ }^{4}$

Tyypillisessä tšastuškassa perusyksikkönä on säkeistö, joka koostuu kahdesta säeparista. Nämä ovat yleensä riimissä toistensa kanssa. Säkeistö koostuu näin ollen neljästä lyhyestä säkeestä. Näin analysoituna tšastuškan rakenne on muotoa ABAB. Olen alla olevaan esimerkkisäkeistöön alleviivannut riimitykset. Käytän myös jatkossa tätä menettelytapaa. 
1. säepari:

A-säe

B-säe

Istuin mina pedai jurou,

katsum mina taivhale.

2. säepari:

A-säe

B-säe

Moli moli, jumalaine,

tšomad rugišt houmhele.

Istun minä petäjän juurella, katson minä taivaalle,

rukoilen, Jumala, hyvää ruista halmeelle.

(Kettunen \& Siro 1935: 142).

Melodiassa yhtä säveltä kohden on useimmiten yksi tavu. Tšastuškan rytminen rakenne on useimmiten nelipainoinen trokee $(8+7+8+7)$, jota on pidetty yhtenä syynä laululajin suosioon ja levittäytymiseen laajoille alueille Venäjällä. (Zemtsovsky 2001: 9-10; ks. Trubetskoj 1987) Suomalaisten rekilauluja pidetään tšastuškan lähimpänä vastineena (ks. esim. Hakamies 1994: 80; Čistov 1976: 203). Rekilaulun ja tšastuškan kaltaiset säkeistötyypit ovat olleet myös Euroopassa yleisiä tanssilaulujen kaavoja (Virtanen 1992: 76).

Tarkastelen sekä kenttämatkoilla keräämiäni että eri lähteistä saamiani lauluja ja niiden piirteitä, lähinnä metriikkaa. Tarkoitukseni on myös tuoda esiin laulujen metriseen analysointiin liittyviä ongelmia. Mitä sitten aion saavuttaa tällä tarkastelulla muuta kuin pajojen metrisen rakenteen? Tarkastelu tuo esiin mm. pajojen rakenteellisen selitysmallin. Toinen seikka, joka itseäni alkoi kiinnostaa oli metrisen mallin suhde esitykseen eli sävelmiin. Miten taustalla oleva kielellinen malli eli mitta sitoo tekstiä rytmiin ja sävelkestoihin? Tämän ajatuksen pohjalta tarkasteluni on myös uuden analyysimenetelmän soveltuvuuden testausta. Tarkasteluni on kuitenkin pääasiassa aineistolähtöistä, sillä uskon, että aineisto osittain ohjaa analyysissä käyttämääni menetelmää. Tästä syystä menetelmä ei välttämättä sovellu sellaisenaan toisenlaiseen musiikkiin, näin ainakin oletan vielä tässä vaiheessa.

Nostan esiin myös kysymyksiä siitä, missä määrin vepsäläisten lyhyet pajot ovat mahdollisesti saaneet vaikutteita venäläisestä tšastuškasta ja mitkä piirteet lauluissa mahdollisesti olisivat tyypillisesti vepsäläisiä. Nämä seikat ovat kuitenkin monien arvailujen varassa ja vaativat vielä tutkimusta, joten kovin syvällisiä ratkaisuja en voi esittää. Tarkoitus onkin tuoda julki erilaisia vaihtoehtoja ja ajatuksia.

\section{Vepsäläiset ja heidän asuinalueensa}

Vepsäläiset kuuluvat suomalais-ugrilaisiin kansoihin, ja kielensä perusteella heidät luetaan itämerensuomalaiseen kieliryhmään. On arveltu, että vepsäläiset ovat olleet Venäjän luoteisosan kantaväestöä (Pimenov ja Strogalštšikova 1994: 19).

Vepsäläisten asuma-alueet rajoittuvat nykyään Venäjällä Äänisen lounaisrannan ja Valkeajärven väliselle alueelle sekä Ojatti-joen yläjuoksun seuduille. Eteläisimmät 
vepsäläisasutukset ulottuvat melkein Tihvinän (karkeasti ottaen n. 300 km Pietarista itään) kaupunkiin asti. Äänisen lounaisrannalla Šokšusta Himjoelle ulottuvalla alueella asuvat äänis- eli pohjoisvepsäläiset ovat muista vepsäläisistä eriytynyt ryhmä. (Mm. Petuhov 1995: 387; Savolainen 1998: 92; Vinokurova 1998: 99.)

On arveltu, että vepsäläisten asuma-alueet ovat aikaisemmin ulottuneet huomattavasti tältä vuosisadalta tunnettuja alueita kauemmas. Arkeologisten tutkimusten perusteella on esitetty, että vepsäläisiä olisi asunut myös Laatokan lounaispuolella sekä Äänisen itäpuolella. (Kotshkurkina 1994: 42-44.)

Vepsäläiset jaetaan nykyään yleisesti kolmeen eri ryhmään: etelä-, keski- ja pohjoisvepsäläisiin. Pohjoisvepsäläiset asuvat Karjalan hallintoalueella Äänisen länsirannalla olevalla kapealla alueella. Keskivepsäläisten asuinalueet sijaitsevat Leningradin ja Vologdan hallintoalueilla. Etelävepsäläiset kuuluvat asuinalueidensa mukaan Leningradin alueen Boksitogorskin piiriin. (Kotskurkina 1989: 164.) Tarkkoja lukuja vepsäläisten kokonaismäärästä ei tällä hetkellä ole mutta 1989 suoritetun väestölaskennan mukaan heitä oli 12500 (Strogalštšikova 1999: 50). Viimeisimmässä väestölaskennassa (2002) ei huomioitu vähemmistökansallisuuksia ja tästä syystä vepsäläisten lukumäärä jäi selvittämättä.

\section{Lyhyt pajo vai tšastuška?}

Kristi Salven (1998: 127) mukaan "pajo tarkoittaa käytännössä pelkästään tšastuškoja". Myös Hakamies (1994: 80) kirjoittaa, että vepsäläisten tšastuškat ovat samanlaisia lauluja kuin venäläiset tšastuškat. Kenttämatkoillani olen kuullut usein puhuttavan niin lyhyistä pajoista kuin tšastuškoista samanaikaisesti, mikä on monesti tehnyt itselleni sekavaksi sen, tarkoitetaanko näillä termeillä aina sittenkään toistensa synonyymeja. Useimmiten lyhyistä pajoista puhuttaessa tšastuškalla on tarkoitettu samaa. Tämän käsityksen saa myös Rürik Lonin (2000: 4) kirjoittamasta Lühüdad pajoized -kirjasta, jossa mainitaan, että "Nečen kirjan täht olen valičenu lühüdoid pajoižid, miččid venäkelel kuctas častuškoikš”. Tämän mukaan vepsäläisten lyhyitä pajoja kutsutaan venäjän kielellä tšastuškoiksi, ja näin ne olisivat sama asia.

Olen saanut kuulla myös toisenlaisia määritelmiä. Tällöin lyhyen pajon ja tšastuškan erona on nähty esimerkiksi se, että "[l]yhyt pajo koostuu pienistä lauluista" eli nelirivisistä säkeistä, jotka eivät ole välttämättä juonellisesti sidottuja. Tämänkaltaisen selityksen sain kuulla mm. Kurban kylän kuorolaisilta.

Viime heinäkuussa (2003) Päžjärvellä olimme tutkimusryhmämme kanssa Marija Cemjonovnan (s. 1927) luona tekemässä haastattelua. Marija esitti meille karhunpelotus- tai -karkotuslaulun. Kun aloimme tiedustella, että oliko tämä laulu lyhyt vai pitkä pajo vastasi Marija, että lyhyt. Johon lisäsin tiedustelevasti, että tšastuškako. Tähän Marija ja hänen poikansa vastasivat yhteen ääneen, että ei tšastuška vaan lyhyt pajo. Aloin kysellä lisää, että miksi laulu ei ole tšastuška, mutta asia jäi siinä tilan- 
teessa käsittelemättä loppuun. Ehkä asiaa on vaikea selittää tai se on niin selvää monille täkäläisille, etteivät he välttämättä osaa kommentoida tutkijan tolkuttaviin kysymyksiin. Marijan poika ehti kuitenkin kommentoida asiaa sen verran, että koska laulu on niin pitkä ja hidas niin se ei ole tšastuška vaan lyhyt pajo. Tässä tapauksessa lyhyt pajo erosi tšastuškasta tempon perusteella. Toinen seikka, jota Marija itse kommentoi laulun lopuksi, oli esityskieli "po vepskij". Marija myös sanoi asian niin, että laulua "voi" kutsua lyhyeksi mutta ei tšastuškaksi. Voiko sitä siis kutsua joksikin muuksikin?

"Tšastuška vai lyhyt pajo?" -kysymykseen on siis jopa paikallisten vaikea antaa määritteleviä vastauksia. Eri seuduilla termit ovat saattaneet tarkoittaa samaa asiaa, toisilla taas eivät. Käytännöt ja tavat kutsua lauluja ovat myös saattaneet vaihdella paikkakunnittain. Seutujen välisessä vuorovaikutuksessa ovat käytännöt saattaneet lisäksi sekoittua. Toisaalta vepsäläisillä näyttää olevan vain muutama termi, joilla he kutsuvat lauluja, kuten lasten laulut (lapsien pajot), pitkät laulut (pitkät pajot), lyhyet pajot ja tšastuškat, häälaulut ja itkut. Näille termeille löytyy sitten alakategorioita, kuten huligaanilaulut (lyhyet pajot tai tšastuškat), työlaulut (lyhyet pajot tai tšastuškat) jne. Toisaalta määrittelyt ovat saattaneet alkaa kehittyä vasta tutkijoiden tullessa kentälle. Tätä ennen ei ole ollut tarvetta määritellä lauluja sen kummemmin, sillä jokainen on tiennyt, mitä laulua lauletaan missäkin tilanteessa ilman määrittelyjä.

\section{Lyhyiden pajojen esittämiskielestä}

Monet tapaamistani laulajista ovat pystyneet esittämään pajoja niin venäjän kuin vepsän kielellä. Joissakin kylissä on ollut myös tapana esittää säkeitä vuoroin venäjäksi vuoroin vepsäksi ${ }^{5}$. Haastatteluja tehdessäni jotkut laulajat ovat jopa kysyneet ensin, laulaako vepsäksi vai venäjäksi. Olen usein vastannut, että kummatkin kielet käyvät, jolloin laulajat ovat aloittaneet laulamisen yleensä vepsän kielellä. Kun laulajat ovat laulaneet osaamansa vepsänkieliset säkeet, ovat he usein lopuksi vielä laulaneet säkeitä myös venäjäksi samalla melodialla.

Usein on käynyt niin, että laulajan esittäessä laulua hän huomaamattaan vaihtaa kielen vepsästä venäjäksi, jopa kesken lauseen. Syksyllä 2002 Haragl-nimisessä kylässä päädyimme tutkimusryhmämme kanssa erään perheen luokse, jossa vietettiin ortodoksisenperinteen mukaista praasniekkaa eli juhlapäivää. Mukanamme oli videokamera ja nauhuri, mikä sai aikaan ehkä sen, että heti juhlahuoneeseen tullessamme alkoi eräs nainen laulaa työ- tai heinäntekolaulua (hidas tšastuška) venäjäksi. Kun hän oli laulanut pari säkeistöä, hän huomasi itse laulaneensa venäjäksi. Siinä samassa hän lopetti hetkeksi laulamisen ja aloitti pian uudestaan samalla melodialla mutta vepsän kielellä.

Tyypillistä on myös se, että laulajat laulavat ns. sekakieltä, jossa osa sanoista on vepsää ja osa venäjää (vrt. suomenruotsi ${ }^{6}$ ). Usein näyttää siltä, että laulajat laulavat 
unohtuneen vepsänkielisen sanan tai lauseen tilalle venäläisen vastineen. Tästä voi helposti päätellä, että lauluja on saatettu kääntää suoraan venäjästä vepsäksi ja tällöin venäjänkieliset sanat muistuvat monille mieleen joissakin kohden paremmin kuin vepsänkieliset sanat. Laulajat itse ovat olleet yleensä sitä mieltä, että vepsänkieliset laulut ovat syntyneet suoraan vepsänkielisinä eikä venäläisistä käännöksistä. Ehkä todennäköisempi syy kielen sekoittumiseen on kuitenkin siinä, että useilla seuduilla vepsäläisten kielenkäyttö on siirtymässä kokonaan vepsästä venäjään. Vielä on kuitenkin seutuja, joilla ihmiset puhuvat vepsää keskenään aivan sujuvasti, kuten Päžjärvellä tai Ladvassa.

Vepsäläisten kielenkäyttöä ja -vaihtoa puheessa on tutkinut mm. Novožilova (2001). Hänen tutkimuksena mukaan vepsäläiset puhuvat valtakulttuurin kieltä suhteellisen hyvin, kun taas vepsää käytetään yhä vähemmän ja vähemmän. Tutkimuksessa olleet vepsäläiset puhuivat sujuvaa venäjää, heidän tarvitsematta edes välillä turvautua vepsän kieleen. Kun piti puhua vepsää, jopa vanhempien ihmisten piti välillä lainata sanoja venäjän kielestä. Vepsäläisten arkipäivän keskustelussa he asettavat puheensa väliin venäjänkielisiä sanoja. Kyseisen tutkimuksen mukaan tämä on tietoista toimintaa.

Olen kenttämatkoillani huomannut myös samanlaisen tilanteen: jotkut vepsäläisistä puhuvat mieluummin venäjää kuin vepsää. Esimerkiksi kun mukana on venäjän- ja vepsänkielisiä, on todennäköistä, että silloin puhutaan venäjää, sillä vain harvat venäläiset ovat opetelleet vepsää. Usein tuntuu, että omaa kieltä ujostellaan. Tästä syystä, kuten myös Salve (1998: 132) kirjoittaa, venäjän kieli pääsee yleensä helposti dominoivaan asemaan. Ainakin tältä se usein vaikuttaa kulttuurin ulkopuoliselle ihmiselle.

\section{Laulut ja improvisointi}

Kun näin Kurban kylässä elokuussa 2001 laulajien esittävän lyhyitä pajoja, tuntuivat laulut perustuvan hyvin pitkälle improvisointiin. Naiset istuivat erään perheen luona olohuoneen sohvalla ja jokainen lauloi lyhyitä pajoja aina sitä mukaa kuin säkeitä keksivät. Laulujen välissä keskusteltiin niitä näitä ja yhtäkkiä, kun joku keksi yhden säkeen, joku keksi toisen. Myöhemmin vertaillessani eri kylissä kuulemiani lauluja keskenään huomasin, että samankaltaiset säkeistöt toistuivat. Usein laulajat esittivät pajoja hiukan eri rytmissä tai tempossa mutta kuitenkin niin, että tietty teksti pysyi samana tai samankaltaisena. Näyttääkin siltä, että laulajilla on mielessään tietty säetai säkeistövarasto, josta he sitten tilanteen mukaan rakentavat koko laulun tai esityksen. On hyvin mahdollista, että laulut ovat aikaisemmin olleet puhtaasti improvisoituja, mutta tietyt helposti muistiin jäävät hyvät riimitykset ${ }^{7}$ ovat todennäköisesti jääneet elämään (ks. Lonin 2000: 4).

Improvisointiin vaikuttaa myös se, että laulujen nykyiset esittämistilanteet ${ }^{8}$ eroavat siitä, mitä ne ovat olleet joskus kymmeniä vuosia sitten. Nykyään lauluja esite- 
tään vain lähinnä praasniekoissa ja erilaisilla festivaaleilla ja monet ovat harjoitelleet näitä tilaisuuksia varten tietyn repertuaarin verran lauluja. Myös useimmat laulajat ovat äänityksen aikana yleensä ilmoittaneet minulle, että 'kaik", minkä jälkeen he ovat todenneet, että eivät muista enempää säkeitä. Tästä saa sen käsityksen, että säkeet oli opeteltu ulkoa. Olen tavannut myös laulajia, jotka eivät ole laulaneet säkeitä ulkomuistista, vaan he ovat esittäneet niitä omista muistiinpanoistaan. Muistiinpanot on aina kirjoitettu venäjän kielellä.

Otan esiin seuraavaksi muutamia hyvin tyypillisiä säkeistöjä, joita on esiintynyt aikaisemmissa lähteissä ja joita olen kylistä nauhoittanut. Kuvaavaa tässä on se, kuinka laulajat esittävät säkeitä kukin hiukan omalla tavallaan varioiden mutta silti pysyen tietyssä säännönmukaisuudessa. Riimitykset ja säkeiden määrät näyttävät olevan pysyviä elementtejä. Hyvin suosittu säkeistö on esimerkiksi käen kukkumisella alkava säe. Sisällön perusteella voi jo päätellä, että seuraavat esimerkit ovat naisten laulamia lauluja. Miehetkin ovat ennen laulaneet pajoja mutta tässä artikkelissa esiintyvät säkeistöt ovat kaikki naisten esittämiä. Miesten pajoissa sisältö on erilainen.

(Noidal, Noitala)

Kukku kukku kägoihut,

sures kuze ladvaižes,

voika voika neitšukaine,

tšomal prihal kaglaižzes.

(Kuku kuku käkönen,

suuressa kuusen latvassa,

itke itke tyttönen

kauniin pojan kaulassa.) (Kettunen ja Siro 1935: 1409)

Kukkub, kukkub kägine,

kuivan kuzen ladvas.

Ribbub, rippub niičukaine,

omal prihäl kaglas. (Lonin 2000: 28)

(Petsoil, Petsoila)

Kukku kukku kägoihud,

kujokuze ladvas.

Voikad voikad nitšukaine

tšomou prihou kaglas. (Kettunen ja Siro 1935: 146)

(Koskenpää)

Kägi kukkub, kägi kukkub,

Nor niičukaine itkeb,

jogen taga sabras.

norel prihäl kaglas.

(Eerola 2000: Koskenpää8/2000MD2/7/1Lpaj)

Myös saman kylän laulajat saattavat varioida tuttua säettä:

(Noidal, Noitala)

Kukku kukku käguško,

Voika voika neitšukaine, sures kuze ladvas.

tšomou prihou kaglas. (Kettunen ja Siro 1935: 141)

Toinen tyypillinen säkeistö, joka kuului useimpien tapaamieni laulajien säevarastoon, on oman ja naapurikylän tyttöjen huivien vertaaminen. Säkeistössä tulee esiin kiusoitteleva kehuskelu, jolla on selvästi tarkoitus saada vastapuoli, toisen kylän tytöt tai 
pojat, peliin mukaan. Naisten laulaessa huivin solmu yleensä aukaistaan ja huivi jätetään vapaasti roikkumaan päähän, jolloin hiukset paljastuvat. Kun laulaja on laulunsa laulanut, hän solmii taas huivin kiinni ${ }^{10}$.

Paik-se tšoma, paik-se tšoma ${ }^{11}, \quad$ kaimeižed ne parembad.

Ozreižed ne prihat ťšomad, $\quad$ Korbleižed ne parembad.

(Huivi kaunis, huivi kaunis, raidat ne paremmat,

Ozroilan pojat kauniit,

Korbalan ne paremmat.) (Kettunen ja Siro 1935: 145)

(Vilhal, Vilhala)

Paik-se oma paik-se čoma, paikas kistid čomembad.

Randaliižed nii ed čomad, Mägeliižed čomem $\underline{\text { bad. }}$

(Eerola 2000: Vilhala8/2000MD1/1)

(Koskenpää)

Paikat omad paikad čomad, paikad cogad čomembad.

Koskenpäässä prihat čcomad, Rädimägel čomembad.

(Eerola 2000: Koskenpää8/2000MD2/7/1Lpaj)

Paik-se oma, paik-se čoma, rüunaižed-ne parembad.

Oma verhis prihäd čomad, Järvläižed-ne parembad. (Lonin 2000: 43)

Arvioitaessa tšastuškan tai lyhyiden pajojen improvisaatioluonnetta tarkastelemieni esimerkkien valossa näyttää siltä, että improvisaatio koskisi enemmän melodiaa, sillä tekstit näyttävät olevan vakiintuneita säekokonaisuuksia. Vastaavanlaisia tšastuškasäkeitä löytyy myös Karjalasta. Seuraavat karjalankieliset säkeet löytyivät T. Kosken (1985) karjalaisia tšastuškoja käsittelevästä teoksesta:

Kuku, kuku, kägözeni, Kuivan kuuzen ladvassa.

Itken minä ulahutan Armahala kaglas. (M. C. Igojeva, Tuloksa, 1967)

Soma paikka, soma paikka, Laijat vielä somemmat.

Yksi on viinatta viizahembi, Se miula on jo mielehembi. (A. V. Akimova, Tunkuda 1979)

Saattaa olla hyvinkin sattumaa, että samankaltaiset säkeet ovat päätyneet Kosken keräämään kirjaan. Säkeet ovat toisaalta voineet kulkeutua vepsäläisten mukana karjalaisten asuttamille seuduille. Sisällöllisesti tarkasteltuna teksti viittaa yhteiseen suomalais-ugrilaiseen perinteeseen ja osaltaan asuinalueeseen. Esimerkiksi käki on tyypillinen Pohjoisen Euraasian alueelle sijoittuva elementti (Hautala 1955: 146). Täällä käen kukkuminen on ollut merkki esimerkiksi kevään tulosta (Karhu 2001; Hautala 1955: 142-146), sillä käkihän aloittaa kukkumisensa toukokuun alussa (ks. esim. Lokki ja Palmgren 1995: 275). Käki on myös symbolisoinut seksuaalisuutta jo muinaisissa kulttuureissa lemmenjumalien hahmoissa (Krogerus 1989: 145). Vepsäläistenkin käellä on tässä selvästi ajallinen ja seksuaalinen merkitys. "Käki kukkuu” -lau- 
setta seuraa yleensä lause, jossa nuori neitokainen itkee, roikkuu tai jopa värisee nuoren pojan kaulassa:
Kukku kukku kägoihud,
kujokuze ladvas.
Voikad voikad nitšukaine
tšomou prihou kaglas.

Säkeessä on paljon sisältötä: kun tulee kevät, nuoren neitosen on ryhdyttävä valitsemaan sulhasta tai muuten voi jäädä ilman. Neitosen on myös jollain tavalla saatava poika kiinnostumaan itsestään. Tällöin tytöt esittelevät kauniita huivejaan ja kehuskelevat tietyn kylän poikien ulkomuotoa:
Paikat čomad paikad čomad,
paikad cogad čomembad.
Koskenpäässä prihat čomad,
Rädimägel čomembad.

Poikien houkuttelu jatkuu myös seuraavanlaisessa säkeistössä:

Minä sanoin kanalle, da ala muni irdalle.

Muni mini pordhile, da kymne munad prihalle.

(Minä sanoin kanalle, älä muni (kadulle) pihalle.

Muni minun portaille, kymmenen munaa pojalle.)

Lyhyiden pajojen säkeistöjen esittämisessä ei aina ole väliä, missä järjestyksessä ne esitetään. Myös Loninin (2000) ja Kettusen ja Siron (1935) säkeistöt on esitetty vailla loogista rakennetta. Myös useimmat äänittämistäni pajoista on laulettu ilman sisällöllistä järjestystä. Yleensä laulajat esittivät säkeistöt siinä järjestyksessä missä ne muistivat. Tämä on saattanut johtua siitä, ettei perinne ole enää ollut pitkään aikaan aktiivinen.

\section{Metriikan teoriaa ja sen ongelmia}

Puhuttaessa laulujen teksteistä ne rinnastetaan yleisimmin lyriikkaan. Laulutekstit eivät kuitenkaan välttämättä ole aina lyyristä runoutta, mutta hyvin usein niihin pätevät lyyrisen kerronnan kuvaukset. Vepsäläisten lyhyisiin pajoihin sopii mielestäni hyvin Kupiaisen (1974: 25) lyriikan määritelmä: 'lyyrinen runo 'sanoo' enemmän kuin pelkkä sanojen sisällys ilmaisee". Lyhyissä pajoissa toteutuu myös lyriikan ihanne; "mahdollisimman vähin sanoin saadaan ilmaistua mahdollisimman paljon". Lyriikkaan rinnastetaan myös sellaiset käsitteet kuin "laulurunous" ja "tunnelmarunous" (Kupiainen 1974: 25). Lyyrisen runon tärkeimpiä ominaisuuksia ovat rytmi ja sointuisuus, joiden avulla runoon luodaan jännitettä ja harmoniaa. Myös lyhyissä pajoissa rytmi ja riimitys tulevat selkeästi esille ja etenkin loppusointu on tärkeä. Kun nämä elementit ovat läsnä, voidaan sanoa, että ollaan tyylillisesti lähellä lyhyttä pajoa. 
Lyriikan tutkiminen edellyttää metriikan sääntöjen tuntemusta. Runomittaoppilla eli metriikalla tarkoitetaan runossa vallitsevan rytmin merkitsemistä tahdin mukaisesti, jossa käytetään apuna runomittoja eli metrumeita. Kupiaisen (1974: 36) mukaan

[r]unomittaoppi lähtee säkeen käsittävästä kokonaisuudesta. Säehän muodostaa useimmiten selvästi myös oman rytmillisen yksikkönsä. Sen kulkua kuunnellen havaitaan siinä nuosuja ja laskuja. Nousut ovat painollisten tavujen kohdalla, laskut painottomien. Yksitavuiset sanat saattavat esiintyä joko nousussa tai laskussa. Näin jaksottuu säe tavuryhmiksi, siten että kussakin ryhmässä on aina yksi nousussa oleva siis painollinen - tavu ja yksi tai useampi laskussa olevia. - -

Äsken mainitulla tavalla saatuja tavuryhmiä nimitetään runojaloiksi tai runopolviksi. Painollinen tavu on aina joko runojalan alussa tai lopussa, ei koskaan keskellä. Runojalka saattaa siis 'katkaista' sanan ja hyvin usein tekeekin sen. Runojalka on nouseva, painottomat tavut (tai painoton tavu) ovat ennen painollista, päinvastaisessa tapauksessa se on laskeva.

Ongelmaksi runon perinteisen runomittaopin mukaisessa metrisessä analyysissä muodostuu se, millä tavoin runon lukija tai analysoija tunnistaa tekstin mitan: nousut ja laskut sekä niihin sijoittuvien kielen yksiköiden suhteet (Leino 1982: 14). Kuten Leino asian ilmaisee, Kupiaisen menetelmä tuo esiin vasta tavuluvun vaihtelun ja tavurakenteen säkeissä. Menetelmä jättää myös tutkijalle liikaa tulkinnan mahdollisuuksia.

Leinon (1982: 14-15) mukaan metriikan tehtävänä on osoittaa runon pohjalla oleva järjestelmä, jonka päälle erilaiset variaatiot ovat rakentuneet. Tällöin on erotettava toisistaan paitsi runomitta ja runo, myös runo ja tietty ainutkertainen esitys tai tietty tapa esittää se. Metriikka tuo esiin esitystapojen pohjana olevan lingvistisen kohteen tietynlaisen mallin, abstraktisen rytmikaavan, jolla voi olla useampia vaihtoehtoisia esitystapoja. (Leino 1982: 87.) Toisin sanoen kaava on vain malli, jolle ei ole määritelty mitään aikaa tai rytmiä. Vasta sen jälkeen, kun abstraktia rytmikaavaa toteutetaan, se liittyy aikaan ja rytmiin. Malli on kuitenkin pysyvä. Tästä syystä laulujenkin runot täytyy irroittaa esityksestä mitan selville saamiseksi.

Metriikka tarkastelee ensi sijassa mitan ja puhutun kielen suhdetta. Hyvin usein tarkastelun kohteena on kirjoitettu kieli. Kuitenkin mitan yksiköt on määriteltävä puhutuksi oletetun eikä kirjoitetun runon pohjalta. (Leino 1982: 62.)

Leinon mukaan metrisen teorian tulisi osoittaa runossa oleva "rytmipakko", jos sitä on, ja toisaalta lukijan tai kuulijan kokema rytmi (Leino 1982: 44-45). Mielestäni metriikan tulisi selvittää ennen kaikkea runon tekijän tai esittäjän mielessä oleva metrinen kaava. Rytmipakko syntyy vasta, kun esittäjällä on mielessään jokin tyyli tai malli, jonka mukaan hän alkaa esittää tai tehdä runoa. Tätä myös Aristoteles (1997: 163) on painottanut aikoinaan teatterimaailman ohjeissaan. Aristoteleen huomautus mitan synnystä kuvaa juuri esittäjän mielessä olevaa rytmipakkoa: 
Aluksi nimittäin käytettin trokeista tetrametriä, koska se sopi satyyrirunouteen, johon sisältyi paljon tanssia; mutta kun puhe tuli näyttämölle, luonto itse löysi sopivan runomitan, sillä jambinen mitta on sopivin keskusteluun.

Leino (1982: 314-315) kuvaa tätä seikkaa auditiivisena vaikutelmana, joka on runoilijalla mielessään. Tämän perusteella runoilija arvioi säkeiden sopivuutta mielessään olevaan abstraktiseen malliin sekä sitä, täyttävätkö ne hänen tyylinorminsa ja ilmaisutarpeensa.

Eri kielissä sanojen painot (pääpaino) tai nousut ja laskut ovat eri paikoissa (ks. Suomi 1988: 42-47; Carlson 2003: 4). Metrisen teorian sääntöjen määrittelemisessä täytyy aloittaa teorian ja kielen vastaavuuksia hallitsevista periaatteista. Työni kannalta merkityksellisin asia on sanapaino. Vepsän kielessä sanapainot vastaavat suomen painotuksia ja yleensä sanapaino on ensimmäisellä tavulla. Vepsän kieli sisältää kuitenkin joitakin pieniä poikkeuksia painojen suhteen. Näillä poikkeuksilla ei kuitenkaan ole ratkaisevaa merkitystä työni tuloksiin.

\section{Mitta ja siihen liittyvää teoriaa}

Metristen kaavojen olemassaolo ja niiden vaikutus runouteen on tiedetty jo kauan. Tiettävästi jo Mesopotamiassa noin 3000 eKr. oli runoja, joissa oli tietty säännönmukainen rytmi ja tietyt metriset kaavat. Mielenkiintoinen seikka myös omalta kannaltani on se, että länsimaisen klassisen musiikin historiassa metriikka oli aluksi kiinteästi mukana rytmiopissa mutta alkoi erota siitä jo 1100-luvulla. (Oksala 1980: 77-82.) Palaan siis tavallaan ajassa taaksepäin, koska tarkoituksenani on tarkastella myös sitä, kuinka laulajan mielessä oleva mitta tai rytmikaava ilmenee esityksessä.

Tavallisin tapa löytää runossa vallitseva mitta on, Kupiaisen (1974: 36) tavoin, tarkastella runoa tavumäärien pohjalta. Tämä kuitenkin saattaa johtaa valtavaan määrän tulkintoja varsinkin pidempien (yli kolmitavuiset) ja toisaalta myös yksitavuisten sanojen kohdalla. Kaksitavuisten sanojen jakaminen painottomiin ja painollisiin ei yleensä tuota ongelmia mutta niidenkin kohdalla voidaaan päästä erilaisiin tulkintoihin.

Hyvin usein ajatellaan, että runomitta vaikuttaa sanavalintaan ja sanajärjestykseen (ks. Kuusi 1963: 135). Runomitta ohjaa näin ollen myös sanojen jakamista mitan suhteen, sillä runoa lausuttaessa on taipumusta lausua se niin, että mitta tulee täyteen (Leino 1982: 51-52; Carlson 2003: 4). Jos mitta ylitetään, rikotaan sääntöä ja runo lakkaa toimimasta, kun kyseessä on mitallinen runo. Milloin mitta ylitetään, milloin mitta jää vajaaksi? Tämä vaatii tietynlaisen teorian pohjakseen. Kuten Leino (1982: 56) asian ilmaisee:

Teorian tulee pyrkiä yleistyksiin ja formuloida yleistyksensä säännöiksi, joiden tehtävänä on osoittaa säkeiden noudattamat periaatteet. Sääntöjen ulkopuolelle jäävät 
säkeet ovat tällöin kyseisen teorian näkökulmasta epämetrisiä. Vasta kun tämä joukko on saatu eristetyksi, kuvausta voidaan yrittää täydentää etsimällä syitä mitan vastaisuuteen - -

Lähden työssäni selvittämään lauluissa vallitsevia käytäntöjä tai periaatteita, joiden mukaan pajojen tekstejä rytmitetään ja jaetaan mitan mukaan. Leino (1982: 58) rajoittaa tutkimuksensa koskemaan vain yhtä metristä pohjakaavaa ${ }^{12}$. Samoin oma tutkimukseni tässä artikkelissa rajoittuu vain yhteen kaavan ja sen ilmenemisiin lauluissa. Ongelmaksi onkin tullut se, miten selvittää tai valita runon pohjalla oleva pohjakaava toisin sanoen mitta niin, että erilaiset tulkinnat jäisivät mahdollisimman vähäisiksi. Lähtöoletukseni on, että lyhyet pajot ovat oma laululajinsa sillä varauksella, että ne ovat saaneet vaikutteita venäläisestä tšastuškasta tai tämantapaisesta hyvin tavanomaisesta laululajista, jonka metrinen kaava useissa tutkimuksissa on osoitettu olevan $8+7+8+7$ (ks. esim. Leisiö 1986: 52). Tämän jälkeen tarkastelen sitä, kuinka kyseinen kaava eli mitta toteutuu, miten mitta ohjaa sanojen sijoittelua jne. Näiden pohjalta laadin sitten säännöt, joiden avulla runoja tulkitaan.

Mitan pituuden ja ominaisuuksien selvittämisessä lähden suuremmasta pienempään: kun olen selvittänyt säkeistöjen, säeparien ja säkeiden rajat, siirryn sanamäärien ja sitten vasta painojen ja tavujen tarkasteluun. Säerajojen hahmottamiseen liittyy myös omia tulkinnan mahdollisuuksiaan, joten pohjaan tarkasteluni myös muiden tekemiin päätelmiin (esim. Lonin 2000, Kettunen \& Siro 1935). Näissä säkeistöt ja säkeet on usein eritelty toisistaan typografisin keinoin (ks. Leino 1982: 76-84). Välimerkkien sijoittelu ja typografiset tyylit ovat myös hyvin tulkinnanvaraisia. Tästä syystä runon sisällöllinen kokonaisuus täytyy ottaa myös huomioon. Toisin sanoen yksi asia on aina yhtä säettä kohden, ja säeparissa on jo kokonainen lause, jonka perään voidaan sijoittaa esimerkiksi piste. Mitan pituuden ja ominaisuuksien selvittämisessä lähden suuremmasta pienempään: kun olen selvittänyt säkeistöjen, säeparien ja säkeiden rajat, siirryn sanamäärien ja sitten vasta painojen ja tavujen tarkasteluun. Säerajojen hahmottamiseen liittyy omia tulkinnan mahdollisuuksiaan, joten pohjaan tarkasteluni myös muiden tekemiin päätelmiin (esim. Lonin 2000; Kettunen \& Siro 1935). Näissä säkeistöt ja säkeet on usein eritelty toisistaan typografisin keinoin (ks. Leino 1982: 76-84).

Aina ei kirjoitusasusta ole apua. Esimerkiksi Kettusen ja Siron (1935) kaikki lyhyet pajot on kirjoitettu huomioimatta runon rakennetta. Riimit helpottavat näissä säeparin tai säkeen rajan löytämistä, sillä riimitykset sijoittuvat yleensä säkeiden loppuun tai alkuun. Myös sisällöllinen kokonaisuus vaikuttaa siihen, miten runon rakenne tulkitaan. Lyhyissä pajoissa näyttää olevan aina yksi asia yhdessä säeparissa. Säepareilla taas on yleensä jokin syy ja seuraus tms. suhde. Esimerkissä käki kukkuu kuusen latvassa, jolloin tyttö itkee pojan kaulassa.

Kukku kukku käguško, sures kuze ladvas, voika voika neitžukaine, tšomou prihou kaglas.

(Kettunen ja Siro 1935: 141.) 
Esimerkissä on säkeet erotettu toisistaan pilkuilla ja säeparit päättyvät riimeihin. Jaan tekstin sisällöllisiin osiin: säkeistö, säepari ja säe. Myös runojen esityksellinen ilmiasu (nuotit tai äänite) helpottavat säkeistöjen eristämistä isommasta tekstimassasta. Musiikissa yksi säkeistö esitetään yleensä omana kokonaisuutenaan, joka erotetaan hyvin usein muista säkeistöistä esimerkiksi välisoitolla tai tauolla. Myös runojen esityksellinen ilmiasu (nuotit tai äänite) helpottavat säkeistöjen eristämistä isommasta tekstimassasta. Musiikissa yksi säkeistö esitetään yleensä omana kokonaisuutenaan, joka erotetaan hyvin usein muista säkeistöistä esimerkiksi välisoitolla tai tauolla.

\section{Lyhyiden pajojen abstrakti rytmikaava ja sen toteutuminen}

Tarkastelen seuraavaksi sitä kuinka valitsemani mitta, josta käytän termiä abstraktinen rytmikaava (ks. Leino 1982: 309), ilmenee säkeissä. Tarkastelen siis sitä, kuinka sanat valitaan ja sijoitetaan niin, että runo toteuttaa valittua mittaa esittäjän näkökulmasta $^{13}$ (ks. Carlson 2003: 4). Näiden pohjalta määrittelen joitakin keskeisiä sääntöjä, jotka kuvaavat lyhyiden pajojen rytmikaavan toteutusta. Valitsemani abstraktinen rytmikaava, $8+7+8+7$, sisältää I ja III säkeessä neljä painollista ja neljä painotonta tavua. II ja IV säe koostuvat tämän mukaan neljästä painollisesta ja kolmesta painottomasta tavusta. Käytän painollisesta tavusta merkkiä + ja painottomasta - . Tämän mukaan valitsemaani mittaa noudattavien laulujen ensimmäinen ja kolmas säe olisivat muotoa +-+-+-+- ja II ja IV säe olisivat muotoa +-+-+-+ . Käytän painollisesta tavusta merkkiä + ja painottomasta - . Tämän mukaan valitsemaani mittaa noudattavien laulujen ensimmäinen ja kolmas säe ovat muotoa +-+-+-+- ja II ja IV säe +-+-+-+ . Rytmikaava toteutuu esimerkiksi seuraavanlaisessa säkeistössä:

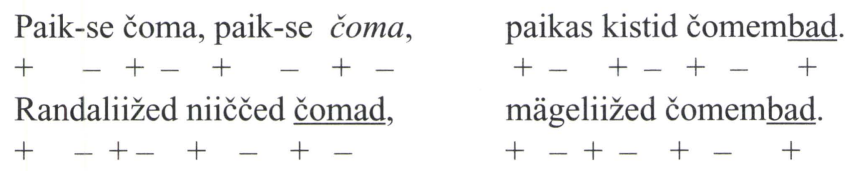

Runon ensimmäinen säe ei tuota tulkinnallisia ongelmia, sillä se sisältää neljä pääpainollista sanaa, jotka ovat lisäksi kaikki vain kaksitavuisia. Tämä on myös rytmikaavan ensimmäinen sääntö: kaksitavuisen sanan painot jaetaan +- Esimerkissä myös säkeen raja on selvä, sillä riimitykset jakavat säkeen omiksi ryhmiksi. Runon rakenne on tämän mukaan ABAB. II ja IV säkeen kolmitavuiset sanat sitä vastoin voidaan tulkita toisinkin eli +- - . Toisaalta yleisesti on vallalla sellainen käsitys, että mitta sanelee sanojen sijoittelua runossa. Jos esimerkissäni käyttämä sana sijoitettaisiin muualle kuin loppuun, olisi tulkinta ehdottomasti toinen. Nyt sanan sijoittaminen loppuun merkitsee mitan toteuttamista esittäjän näkökulmasta. 
Seuraavassa esimerkissä säkeistö koostuu edellisen esimerkin tavoin yhdestä asiakokonaisuudesta. Säeparit päättyvät riimeihin ja säkeet voidaan selvästi erottaa toisistaan lauserakenteen pohjalta: päälause ja sivulause. Rytmikaava ei kuitenkaan toteudu II ja IV säkeessä ja säkeistöä voidaan pitää mitanvastaisena.

Kägi kukkub, kägi kukkub,

$+-+{ }_{-}++_{-}$

Nor niičukaine itkeb,

$+(-)+-+-+-$ jogen taga sabras. (Eerola: 8/2000MD2/7/1Lpaj)

$+-+-+-$

norel prihäl kaglas.

$+-+-+-$

Jos säe lausuttaisiin vahvasti runomittaa korostaen eli skandeeraamalla, se ei toteuttaisi mittaa. En silti sulje säettä pois mitanvastaisena, vaan tarkastelen säkeistöä myöhemmin. Osoitan sen, kuinka laulaja mielessään noudattaa valittua mittaa. Olen käyttänyt Nor-sanan yhteydessä merkkiä (-) kuvaamaan puuttuvaa painotonta tavua. $\mathrm{Pa}$ laan tähän myös myöhemmin. Tarkastelen seuraavaksi sitä, kuinka säkeessä olevaa kolmitavuista sanaa täydennetään lisäsanalla, jotta säkeestä saataisiin mitallinen.

Paik-se tšoma, paik-se tšoma, $\quad$ kaimeižed ne parembad.

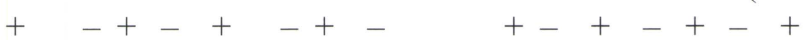

Ozreižed ne prihat tšomad, $\quad$ korbleižed ne parembad

$++_{-}^{+}+-_{-}++_{-}++_{-}+$

Kolmitavuisten sanojen perään lisätään usein jokin lyhyt sana, jolla ei aina ole leksikaalista merkitystä. Tällaisia ovat mm. vu, $d a, a$, $i$, se jne. Tästä voidaan johtaa rytmikaavan toinen sääntö: jos kolmitavuinen sana alkaa säkeen, sanan perässä oleva täydentävä lisäsana (partikkeli, pronomini jne.) asettaa kolmitavuisen viimeiselle tavulle painon, jolloin täydentävä sana osuu jalan painottomalle osalle. Myös pronomineillä täydennetään kolmitavuisten sanojen yhteydessä mittaa. Seuraavassa esimerkissä sä-sanan voi jättää myös pois ilman, että merkitys muuttuu. Tällöin säkeestä tulee kuitenkin mitanvastainen.

Saakko sinä maamuskoa,

$+\quad-+-+-+-$

Net-žä virtaan net-žä tatan,

$+-+-+++-$ rodit mindei gorälle.

(Eerola:Ozroil9/2002Dat1(b)26Lpajo) oigenžid sä rahvaze. $<=$ sä

$+{ }_{-}+{ }_{-}+{ }_{+}$

Tässä (Eerola: Ozroil9/2002Dat1(b)26Lpajo) myös I säkeessä lisätään lisätavu täydentämään sanaa mamusko. Onkin tyypillistä, että laulettaessa sanoja muutetaan hellittelevimmiksi ja enemmän ehkä runomaisemmiksi. Seuraavassa säeparissa esiintyy myös täydentävä pronomini mä: 
III-säe

Katsustin mä kužhaižhe,

$+{ }_{-}+{ }_{-}+{ }_{-}$
IV-säe

kümne munašt suhudhe. (Kettunen ja Siro 1935, 140)

$+{ }_{-}+{ }_{-}+{ }_{-}$

Esimerkissä III säe jää vajaaksi. On mahdollista, että esityksessä on ollut tässä kohden täytetavu, jota kerääjät eivät ole halunneet merkitä ylös (palaan tähän myöhemmin). Seuraavassa esimerkissä (Eerola: 8/2000MD2/7/1Lpaj) kolmitavuinen sana sattuu I ja III säkeen loppuun. Ilman $d a$-lisäsanaa säkeet olisivat mitanvastaisia.

Minä sanoin kanalle, da

+ - + - + - + -

Muni mini pordhile, da

$+{ }_{-}++_{-}+-$ ala muni irdalle.

$+-+-+-+$

kümne munad prihalle.

$+{ }_{-}+{ }_{-}++$

Olen tarkoituksella merkinnyt tummalla -le-tavut enkä $d a$-sanaa, koska näyttää siltä, että laulajat haluavat sijoittaa riimit painollisille iskuille. Olen myös tarkoituksella sijoittanut pilkun kanalle-sanan perään mutta jättänyt kuitenkin $d a$-sanan tähän säkeeseen. Tämä osoitaa sen, kuinka typografiset merkinnät saattavat aiheuttaa tulkinnallisia erimielisyyksiä mitan merkinnässä. Esimerkiksi seuraava säepari (Lonin 2000: 32) oli kirjoitettu näin:

\section{Lad'ba mindei rikota,}

ka minun mel'hišt' navetta.

Laulaja kuitenkin todennäköisesti esittää tämän:

Lad'ba mindei rikota, $\mathrm{ka}$

minun mel'hišt' navetta.

Näin riimit saadaan osumaan painollisille iskuille, jolloin mittaa tulkitaan oikein. Tämä seikka osoittaa myös sen, että laulajat mahdollisesti ajattelevat säeparia kiinteänä yhtenä kokonaisuutena. Tällöin rytmikaava pitäisi ehkä kirjoittaa +-+-+-+ -+-+-+-+ , eikä niin, että kaava jakautuisi kahteen osaan ${ }^{14} . K a$-sanan voi jättää myös pois ja runo toimii yhtä hyvin mutta ensimmäinen säe jää tällöin lyhyeksi. II ja IV säkeiden alussa olevat lisätavut voitaisiin hyvin usein tulkita myös anakruuseiksi, mutta mielestäni tavujen tehtävä tässä on täydentää rytmikaavaa. Tätä ajatusta puoltaa myös se, että kun säkeissä on tavuja riittävä määrä, ei tällöin myöskään esiinny lisätavuja säeparin rajoilla.

Nelitavuiset sanat voidaan yleensä tulkita lähes poikkeuksetta kahden kaksitavuisen sanan mukaan:

III-säe IV -säe

Koskenpäässä prihat čcomad, Rädimägel čomembad. (Eerola: 8/2000MD2/7/1Lpaj)

$+{ }_{-}^{+}+++_{-}++_{-}++\ldots+$ 
Siizutid sä jogezile,

$+-+-+-+-$

I-säe

Haragiine lendleze,

$+-+\ldots+-+$ oigenzid sä rahvaze. (Eerola: Vilhala8/2000MD1/1)

$++_{-}+{ }_{-}+$

II-säe

dorogaine kändleze (Lonin 2000, 20)

$+\ldots+\ldots+\ldots$

Rytmikaavan kolmas sääntö kuuluu: nelitavuiset sanat tulkitaan kuten kaksi kaksitavuista sanaa. Seuraavassa esimerkissä on III säkeessä nelitavuinen sana, jonka tulkitsen kuten edellä olen esittänyt. Säeparin viimeisessä säkeessä (IV) on mielenkiintoinen lisätavu -žes. Olen aikaisemmin esittänyt vastaavanlaisen säkeen ilman tätä lisätavua, jolloin säkeestä tuli mitanvastainen.

Mitanvastainen:

III-säe

IV-säe

Nor niiččukaine itkeb, norel prihäl kaglas. (Eerola: 8/2000MD2/7/1Lpaj)

$+(-)+-+-+-$ $+-+-+-$

Mitallinen:

Voika voika neitšs $\underline{\text { kaine, }}$ tšomal prihal kaglaižes. (Kettunen ja Siro 1935, 140) $+{ }_{-}+{ }_{-}+{ }_{-}+$

Rytmikaavan neljäs sääntö on: jos II ja IV -säkeen viimeinen sana on kolmitavuinen kolmitavuisen sanan viimeinen tavu saa painon. Tätä seikkaa puoltaa myös se, jos kyseinen tavu on riimissä edeltävän säeparin kanssa. Mitan selvittäminen seuraavasta, hieman monimutkaisemmasta säkeistöstä edellyttää, että tiedetään, miten mittaa on sovellettu kaikissa säkeistön säkeissä. Jos tarkasteltaisiin vain kahta viimeistä säettä, saattaisi tulokseksi tulla jotain muuta. Tarkastelen aluksi säkeistöä huomioimatta riimejä, jolloin mitat voisivat näyttää esimerkiksi tältä:

Mina istun iknan veres, $\quad$ čoma cvetaine kädes.

$+-+-+-+-$

$+-+\ldots+$ + -

Kaik silmäižed valutihe,

$+(-)+--+-+-$

maksaižen varastades. (Lonin 2000: 13)

$+-{ }_{-}+{ }_{-}+$

(Minä istun ikkunan ääressä, kaunis paita kädessä.

Kaikki silmät vuotavat, sulhasta odotellessa.)

Jos riimityksiä ei oteta huomioon tämän säkeistön analyysissä, voidaan epäillä, että esittäjällä on sattunut jokin kömmähdys koko tekstin suhteen. Jälkimmäiset säkeet II ja IV ovat mitanvastaisia sanapainojen mukaan skandeerattaessa. Lisäksi III säkeeessä oleva valutihe-sana ei ole riimissä ja sisältää ylimääräisiä tavuja tai väärän taivutuksen. Tällä tavalla analysoituna esimerkiksi Loninin Lühüdad pajoized -kirjasen (2000) säkeistöistä vain kolmannes olisi mitallisia. Asiaa onkin pelkkien tekstien pohjalta vaikea selittää muuten kuin toteamalla nämä kaikki mitanvastaisiksi. Loninin 
kirjassa ei ole myöskään kirjattu kuin muutama täytetavu, joten on myös syytä epäillä, että osa on jätetty pois, koska ne eivät sinällään kuulu puhuttuun tekstiin. Omissa äänitteissäni lisätavujen ilmeneminen on varsin yleistä, sillä lähes jokainen laulaja on niitä käyttänyt täydentämään rytmikaavaa.

Olen tullut siihen johtopäätökseen, että painottomien tavujen merkitys esitettäessä laulua ei ole niin suuri. Tärkeimmiksi muodostuvat painolliset iskut (ks. esim Laitinen 2003: 227), joille pyritään myös aina sijoittamaan jokin tietty sana tai tavu. Tärkeintä lauluissa on saada II ja IV säkeen viimeiselle painolliselle iskulle riimittävä tavu, jota myös laulettaessa usein painotetaan voimakkaasti (aksentti). Tästä syystä sanat usein näennäisesti jaetaan metriikan oletussääntöjen ${ }^{15}$ vastaisesti (Carlson 2003 : 4). Myös Leino (1982: 314) mainitsee, että lauluissa usein rikotaan metrisiä rakenteita. Tätä seikkaa ohjailee laulajan mielessä oleva tyylinormi ja tässä tyylissä olevien painojen määrä. Laulaja ei välttämättä itse huomaa rikkovansa metristä mallia eikä kuulijakaan huomaa mitään mitanvastaista, jos tyylinormia toteutetaan.

Lähden nyt analysoimaan runon säkeitä tavallaan väärinpäin niin, että asetan II ja IV säkeen riimeille ensin painon ja muut sanat jaan vapaasti tämän mukaan.

Mina istun iknan veres,

$+-+-+-+-$

Kaik silmäižed valutihe,

$+\quad++-+-+-$ čoma cvetaine kädes.

$+-+\ldots+\ldots$

maksaižen varastades.

$+\quad++-++$

Riimien mukaan analysoituna säkeistöstä saadaan mitallinen. Tämä tulkinta rikkoo metrin ja sanapainon sääntöjä, kun lähestyin metriä ensinnäkin esityksen eli tyylinormin kautta. Esimerkki kuitenkin osoittaa sen, että laulajalla on mielessään koko ajan sama mitta, vaikka hän jakaakin tavut väärin. Kuulijalle ja esittäjälle tärkeimmät asiat kuitenkin toteutuvat: riimit osuvat kohdalleen ja tavuja on jokaisella iskulla. Onko tämä myös tyylinmukaista lyhyen pajon toteutusta? Mahdollisesti on. Olen hyvin usein huomannut, että jos joku esittää pajoa, niin tällöin monet mukanaolijat saattavat yhtyä riimeihin vaikka eivät muuten laulaisikaan mukana. Tämä seikka osoittaa sen, että säkeiden loppu ja varsinkin säeparin loppu on säkeistön tärkein kohta (ks. Laitinen 2003: 239). Esimerkin pohjalta voidaan alustavasti laatia lyhyiden pajojen rytmikaavan viides sääntö, joka liittyy tyylinmukaiseen mitan tulkintaan: jos riimit (loppusointu) sijaitsevat II ja IV säkeissä, painot jaetaan näissä säkeissä siten, että riiminä oleva tavu saa painon. Tämän säännön mukaan monet mitanvastaisilta näyttävät säkeistöt muuttuvat mitallisiksi. Tämä kuitenkin osoittaa sen, että laulajilla on mielessään sama malli mutta sanojen sovittaminen tähän malliin ei aina noudata metrin kielellisiä sääntöjä.

Esimerkki tuo esiin metrisen tarkastelun puutteita etenkin, jos lähtökohtana on löytää laulajan mielessä oleva tai laulujen taustalla vaikuttava abstrakti rytmikaava. Toinen puute koskee sitä, kuinka esittää kaksitavuisten sanojen jakaminen silloin, kun 
säkeessä on vain kolme kaksitavuista sanaa. Tällöinhän mitta olisi +-+-+- , joka ei ole enää mitallinen. Olen kuitenkin huomannut, että laulajilla on kuitenkin pyrkimys toteuttaa esittämäni rytmikaava. Esitys ja tyylinormien vaikutus on siis myös otettava huomioon analyysissä.

Kolmas seikka, joka metrisessä tarkastelussa jää puuttumaan on säerajan kuvaaminen. Varsinkin II ja III säkeen väli kaipaa tarkennusta selittämään abstraktia rytmikaavaa, sillä pajoissahan säeparit esitetään tai lausutaan kiinteästi yhdessä. Monet ihmiset ovat esittäneet minulle myös lausuen lyhyiden pajojen tekstejä, jolloin tapana on ollut lausua koko säkeistö kerralla ilman taukoa säeparin välissä. Ehkä tässä ajatuksena on todellakin, että yksi säkeistö on kiinteä yhtenäinen kokonaisuus sisällöllisesti. Tällöin säeparin välissä ei voi pitää minkälaista taukoa tahansa, jos halutaan lisäksi noudattaa tyyliä. Näiden seikkojen tarkastelu vaatii kuitenkin lisätyökaluja.

\section{Säkeen raja ja vaihtoehtoinen mitta}

Esityksen ja mitan suhdetta on tutkittu varsin vähän. Tästä syystä monet käsitteet varsinkin laulutekstien metrisessä tarkastelussa ovat vielä hakemassa muotoaan. Lähden pohtimaan asiaa ristiriitaisten säkeiden kautta. Yhtenä ongelmana edellä oli selvittää laulajan mielessä oleva kaava ja toisaalta metrisen mallin kyvyttömyys esimerkiksi ottaa huomioon riimitystä. Otan esimerkiksi laulun, jonka yksi säkeistö (esimerkki 1) osoittautui mitanvastaiseksi sanapainojen mukaan analysoituna. Laulajalla oli selkeä käsitys melodiasta ja rytmistä ja tästä syystä nuotintaminenkaan ei tuottanut ongelmia. Vain muutaman kerran laulaja epäröi rytmin kanssa ja tämäkin johtui siitä, ettei hän omien sanojensa mukaan muistanut tekstiä.

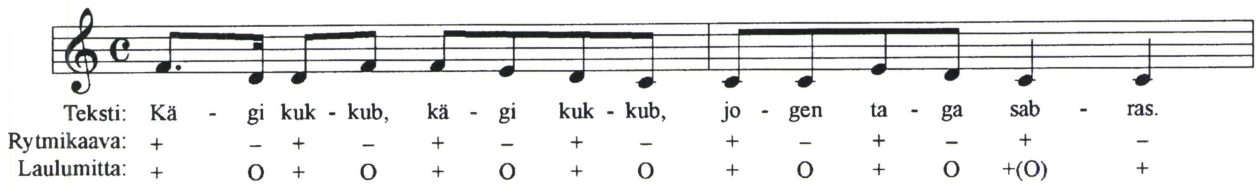

ESIMERKKI 1. Lyhyt pajo Koskenpäästä, ensimmäinen säe. Äänitetty Konskenpäässä (Nadporosh'e) elokuussa 2000 (Eerola: 8/2000MD2/7/1Lpaj). Esittäjä Anna Šulgina.

Esimerkissä on uusi käsite: "laulumitta". Heikki Laitisen (2003: 209) mukaan laulumitan tarkoituksena on kuvata sitä, kuinka runo on laulettu. Laulumitan tehtävänä on tässä myös kuvata metrisen analyysin eroavaisuuksia verrattuna metriseen analyysiin. Toisin sanoen laulumitan tehtävänä on täydentää rytmikaava vastaamaan tyylinormin mukaista käytäntöä.

Olen merkinnyt rytmikaavassa ja laulumitassa painot samoilla merkeillä, jotta luettavuus säilyisi mahdollisimman yksinkertaisena. Painottomat iskut olen merkinnyt laulumitassa O-merkein osaltaan siitä syystä, että tällöin on helpompi hahmottaa rytmikaavan ja laulumitan eroja. Yhden säeparin pohjalta ei kannata kuitenkaan tätäkään 
laulua lähteä vielä tulkitsemaan, koska emme välttämättä tiedä, kuinka hyvin laulaja hallitsee tyylinormia tai mittaa. Tarkastelen seuraavaksi laulajan esittämiä muita säkeitä (esimerkki 2), jotka osoittavat sen, kuinka mitta tai rytmikaava hallitsee laulajan esitystä.
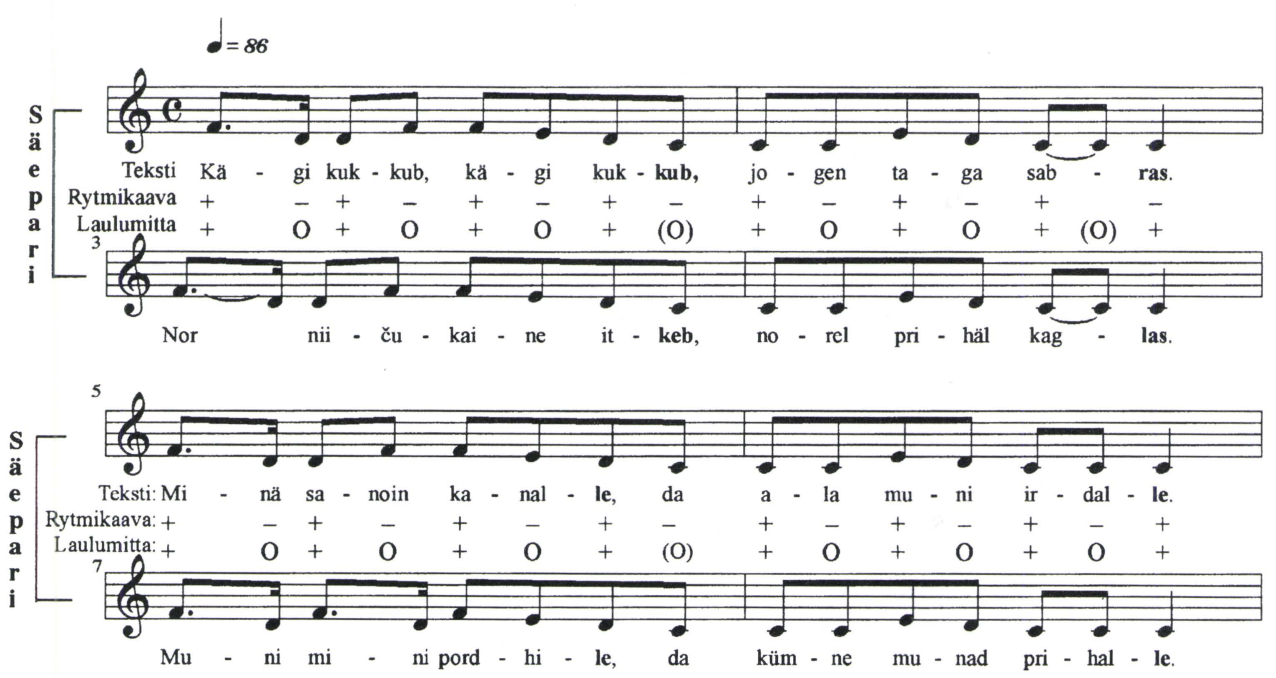

ESIMERKKI 2. Lyhyt pajo Koskenpäästä. Esittäjänä Anna Šulgina. Laulun kaksi säkeistöä.

Tyypillistä Šulginan esityksessä oli, ettei hän juurikaan pitänyt taukoja säkeistöjen välissä, vaan esitti kaikki säkeistöt peräkkäin. Hän lopetti laulamisen sanomalla "kaik". Tämä esimerkki kuvaa tilannetta, jossa laulaja on opetellut ulkoa säkeet ja esittää nopeasti jännittävässä äänitystilanteessa osaamansa laulut. Todennäköistä on, että säkeistöjen välissä on ollut aina lyhyet tauot esimerkiksi välisoittoa varten, mutta tässä esimerkissä niitä ei ole.

Esimerkissä 2 olen käyttänyt erilaista melodian merkintätapaa. Olen jakanut neljäsosanuotit kahdeksi kahdeksasosaksi ja sitonut ne kaarilla. Laulumitan kohdalle olen sijoittanut uuden (O)-merkin painottoman iskun kohdalle. Esimerkin jälkimmäinen säkeistö osoittaa, kuinka laulaja jakaa muiden säkeistöjen tekstit. Loppuosa laulusta eteneekin jälkimmäisen säeparin mukaan, mikä toisaalta osoittaa rytmikaavan toteutumista ja sen, että laulajalla on sama mitta mielessään. Esimerkin I säkeistöön sopii nyt myös viides sääntö, jonka mukaan riimi määrää tavujen jakamisen. Ensimmäinen sääntö ei kuitenkaan nyt toteudu ja tästä syystä sitä on täydennettävä: kaksitavuisen sanan painot jaetaan +-, mutta jos kaksitavuisia sanoja on säkeessä vain kolme kappaletta, toteutetaan sanojen jakamisessa lisäksi viidennen säännön riimiehtoa.

Esimerkissä 2 näkyy myös lisätavujen käyttö. Jälkimmäisessä säkeistössä esiintyy sana $d a$, jolla voi olla myös sanallinen merkitys mutta tässä pidän sitä enemmän mittaa täyttävänä lisänä. $D a$-tavua ei voi pitää riimittävänä, vaan riimitys tapahtuu le- 
tavulla, koska se osuu jokaisessa säkeessä samaan kohtaan. Lisäksi le-tavu on aina painollisilla iskuilla.

Minä sanoin kanalle, da ala muni irdalle.

Muni mini pordhile, da kümne munad prihalle.

Toisaalta $d a$-tavu voidaan tulkita myös anakruusiksi (kohotavuksi), jolloin II ja IV säkeiden rytmikaavat olisivat -+-+-+-+ . Tämä tulkinta osaltaan puoltaa laulumitassa olevan vaihtoehtoista toteutusta osoittavan (O)-merkin käyttöä. Jos (O)-merkkiä sovelletaan myös rytmikaavaan, voidaan säkeiden kaavat kirjoittaa muotoon:

I ja III säe: $+-+-+-+(-)$,

II ja IV säe: $(-)+-+-+-+$.

Jatkossa tarkoitan laulumitassa olevalla $(\mathrm{O})$-merkillä painotonta tavua, joka voidaan joskus jättää pois. Lisäksi jossain tapauksissa merkin kohdalle osuva tavu voidaan siirtää seuraavalle painolliselle iskulle. Tällöin kyseeseen tulevat vain riimittävät tavut, jotka muuten osuisivat painottomalle iskulle tai eri kohtaan seuraavan säkeen riimin kanssa.

\section{Säeparin välinen raja abstraktissa rytmikaavassa}

Säkeiden välinen raja on metrisessä tarkastelussa aiheuttanut kummastusta. Metriikan työkalut tuntuvat usein loppuvan kesken varsinkin, kun kuvauksen kohteena ovat laulettujen runojen säkeiden rajat ja niiden välissä olevat tauot (esim. Laitinen 2003: 233-234; Leisiö 2000: 18). Leinon (1982: 89) mukaan tässä ei välttämättä tarvitse käyttää mitään merkkiä, sillä käsitteet säkeenraja ja säeparinraja ${ }^{16}$ tekevät asian tarpeettomaksi. Lisäksi hän huomauttaa kyseen olevan vain siitä, että säkeenraja täyttää rytmikaavassa olevan paikan, johon muuten voisi sijoittua nousu tai lasku. Tietyn mitan toteutuminen vaatii kuitenkin, että rytmikaavassa on tietyssä kohden tauko. Tästä Leino (1982: 89) käyttää termiä fonologinen tauko ${ }^{17}$. Leisiön (2000: 18) mukaan metriikan ongelmana varsinkin musiikkia tutkittaessa on aikamuuttujan poisjättäminen. Jos taas ajatellaan abstraktia rytmikaavaa eli metristä pohjakaavaa, niin nämä eivät ole sidottuja mihinkään aikaan. Vasta silloin, kun ne toteutetaan, on aikamuuttuja mukana.

Toisaalta oikean mitan toteuttaminen tuntuu edellyttävän tietyn mittaista taukoa säkeiden, säeparien ja säkeistöjen välille. Tauon esiintymiseen ja sen pituuteen vaikuttavat tietyt tyylinormit. Varsinkin nopeiden lyhyiden pajojen abstraktiin rytmikaavaan kuuluu pieni tauko säeparien väliin. Ainoastaan tämän tauon esiintymisidän mittaan kuuluvana. Esimerkiksi säkeistöjen välinen aika voi olla mikä tahansa ja täs- 
tä syystä sitä on vaikea merkitä. Mitan toteuttaminen loppuu käytännössä IV säkeen viimeiseen painolliseen riimitavuun. Tämän jälkeen voi käydä välillä vaikka kahvilla ja lausua sitten uuden pajon ${ }^{18}$. Tyylillisesti näyttää kuitenkin siltä, että I ja II säkeiden väli sallii myös tauon mutta tämän tauon merkintä sisältyy jo (O)-merkkiin. Säeparin rajaa ei sitä vastoin merkitä eikä sen mitalliseen toteuttamiseen liity sääntöä.

Tyylinormi näyttää edellyttävän, että säeparit pitää lausua tai esittää kiinteästi yhdessä. Tällöin rytmi on säännöllistä, mutta toisaalta myös vaihtelevaa. Säeparien välissä on tauko, jolla on abstraktinen pituus eli se voi olla esityksessä mikä tahansa. Tauon pituudella on kuitenkin jokin mitta, jonka se saa runon poljennosta tai askeltamisesta (ks. Leisiö 2000: 18). Tästä syystä näen tärkeänä, että abstrakti rytmikaava sisältää merkin, joka ilmoittaa tauon paikan ja pituuden. Käytän tässä säeparien välissä olevan tauon merkkinä Leisiön (2000: 19) esiin nostaman metrisen tyhjiön merkkiä Ø (ks. esimerkki 3).

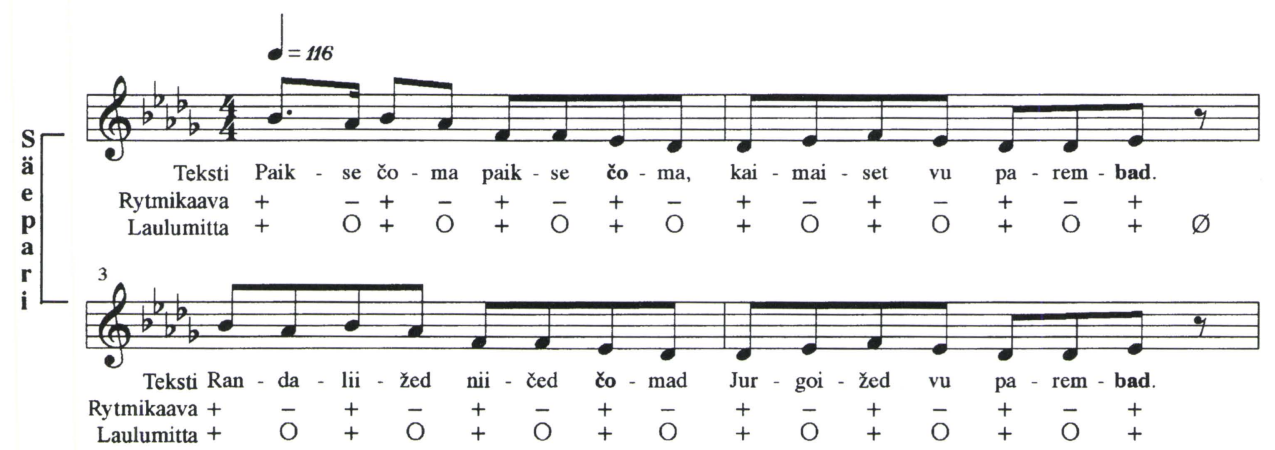

ESIMERKKI 3. Lyhyt pajo Ozroilin kylästä. Esittäjänä on Tsvetkova Nadežda Egorovna. Äänitetty 29.8.2002. (Eerola: Ozroil9/2002Dat1(b)26Lpajo).

Laulun nuotintaminen sujui lähes ongelmitta. Tämä johtui ehkä osaltaan siitä, että laulajan ääni oli kirkas ja hän lauloi melko voimakkaasti. Melodiassa oli alussa joitakin eroavaisuuksia muihin säkeisiin verrattuna, mutta kun laulaja oli esittänyt muutaman säkeen, väheni melodian muuntelu loppua kohden. Monet laulajat venyttävät säkeen ensimmäistä nuottia, eikä aina ole selvää, onko tarkoitus alkaa hiukan koholta vai tarkalleen iskulta - näin myös tässä esimerkissä. Esimerkissä on myös lisätavu, joka nyt on II ja IV säkeistössä oleva vu. Lisätavu täydentää jälleen sitä edeltävää kolmitavuista sanaa.

II säe päättyy rytmikaavan mukaan iskulliseen tavuun, joka on myös riimillinen tavu. Laulaja kuitenkin noudattaa tiettyä mielessään olevaa musiikillista pulssia ja alkaa toisen säkeen tarkalleen nuottiesimerkin mukaan. Esimerkki osoittaa, kuinka tiivis paketti lyhyen pajon yksi säkeistö on. Tämän ja edellisten esimerkkien pohjalta voi sanoa, että säkeiden rajat määräytyvät prominenttien tavujen (riimit) ja yhden tauon mukaan. Tauko tulee aina II ja III säkeen väliin. Tässä välissä olevaa (II säkeen lopussa) prominenttia tavua (riimittävä tavu) usein painotetaan esityksessä. Rytmikaava osoittaa sen paikan, jossa runon mitallinen toteutus mahdollistaa tauon. Myös tämä 
tulkinta edellyttää merkitsemään tauon abstraktiin rytmikaavaan. Tauon pituus on tässä esimerkissä yhtä pitkä kuin painottoman tavun. Metrisen tyhjiön merkkihän tavallaan korvaa tässä poisjätetyn painottoman tavun paikan.

Esimerkissä 3 oleva viimeinen kahdeksasosatauko ei mielestäni kaipaa tyhjiön merkkiä, koska laulu laulettaessakin päättyy viimeiseen prominenttiin tavuun. Musiikillisen ajan mukaan tulkittuna laulu loppuu vasta tauon jälkeen, mutta kielellisen ajan mukaan laulu päättyy viimeiseen tavuun. Toisaalta kappale voidaan myös pysäyttää kuin seinään viimeisen nuotin kohdalle, jolloin taukoa ei edes synny, esityksen kärsimättä. Teoriassa on myös mahdollista aloittaa heti uusi säe viimeisen tauon kohdalta. Lisäksi viimeistä taukoa voidaan pidentää rajattomasti, ja näin esityksissä usein tehdäänkin. Näiden seikkojen takia en näe mahdolliseksi määritellä säkeistön viimeisen tauon pituutta. Leinon (1982: 312) mukaan prominenssi ja tauko eivät riitä kuvaamaan reaalisten säkeiden rytmistä variaatiota. Toisaalta kaavan on myös pystyttävä kuvaamaan ne paikat, joissa rytminen variaatio on mahdollinen.

Kun kuuntelin esimerkin 4 sävelmää, aloin miettiä metrisen tyhjiön pituutta. Voiko tyhjiön pituutta varioida? Eikö mitan toteuttamiseen riitä vain, että pidetään säännöllisesti tauko tietyssä paikassa tekstiä siten, että tauon pituus voi vaihdella? Mielestäni laulussa mitta toteutuu, vaikka tauon pituus varioi.

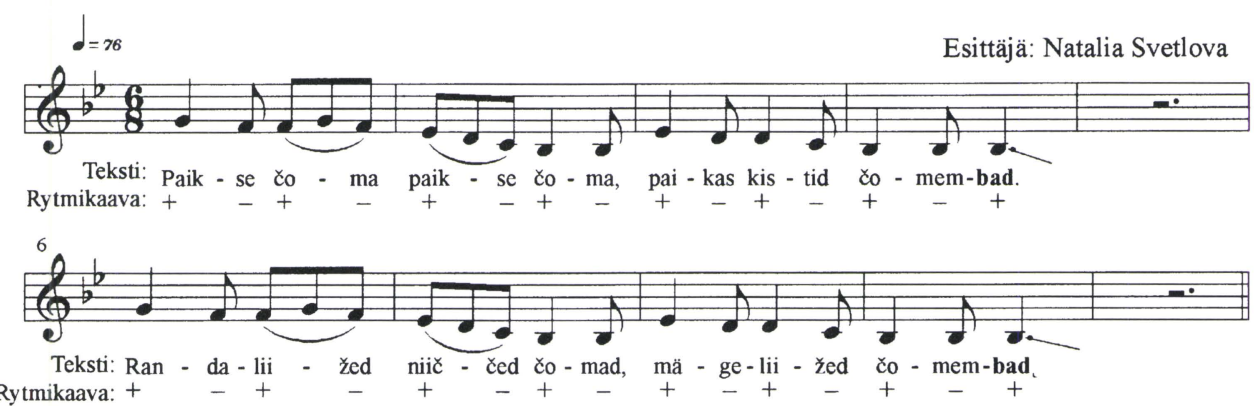

ESIMERKKI 4. Työlaulu tai heinänkorjuulaulu, äänitetty Vilhalan kylässä elokuussa 2000. Esittäjä Natalia Svetlova. Tekstin litteroinnissa avustanut Svetlana Hiekonen. (Eerola: Vilhala8/ 2000MD1/1.)

Olen merkinnyt esimerkkiin tekstin lisäksi rytmikaavan ja jättänyt laulumitan vielä tässä vaiheessa pois, koska laulumitan esittäminen vaatii nuotin kirjoittamista toisella tavalla. Nuotti on siinä mielessä viitteellinen, että säeparin lopussa oleva $\mathrm{bad}$-tavu venyy todellisuudessa ehkä pitemmäksi tai jää mahdollisesti joskus lyhyemmäksi kuin mitä nuotti antaa ymmärtää. Säeparin perässä oleva tauko on säeparin välissä melko säännöllinen mutta viimeisen säkeen jälkeinen tauko ei aina ole välttämättä juuri yhden tahdin mittainen. Lisäksi säkeistön lopussa laulaja ei pitänyt taukoa säännöllisesti 6/8-rytmin mukaan. Näitä asioita on vaikea tässä osoittaa nuotein, sillä se vaatisi koko esityksen analysoimista. 
Esimerkki osoittaa sen, että tekstin mitallinen toteuttaminen on mahdollista, vaikka tauko ei olekaan 1/8- tai 1/4-nuotin pituinen. Pääasia on, että tauko on säännöllinen (esiintyy aina samassa kohtaa), jolloin se on myös tavalla tai toisella sidoksissa esitykselliseen pulssiin. Tästä syystä määrittelen metrisen tyhjiön näyttämään tässä vain tauon paikan, ilman esityksellistä aikaa. Rytmikaava näyttää tauon lisäyksen jälkeen tältä:

$\begin{array}{ll}\text { I-säe } & \text { II-säe } \\ +-+-+-+(-) & +-+-+(-)+\varnothing \\ \text { III-säe } & \text { IV-säe } \\ +-+-+-+(-) & +-+-+(-)+\end{array}$

\section{Säkeistön loppu ja sen kuvaus abstraktissa rytmikaavassa}

Säkeistön loppu on ongelmallinen juuri siitä syystä, että esimerkiksi esitettäessä joskus säkeistöt lopetetaan viimeiseen riimiin, joskus laulun loppua venytetään hyvin pitkäksi. Etenkin työlaulujen kohdalla olen havainnut, että laulujen viimeistä säveltä ja tavua ikään kuin kuuluu venyttää pitkäksi. Tämä voi olla jonkinlainen tyylinormi.

Työlauluissa on harvemmin säestyssoitin mukana, joten ulkopuolinen rytmittävä elementti ei myöskään sido viimeisen nuotin pituutta. Tästä syystä on mahdollista venyttää nuottia ja aloittaa seuraava säkeistö vapaasti. Viimeisen nuotin pituus on kiinni lähinnä laulajan taidosta. Toisin sanoen nuotti kestää usein niin kauan kuin laulajalla riittää ilmaa keuhkoissa. Ehkä venytyksen tarkoitus on osaltaan osoittaa hyvän laulajan tai voimakkaan ihmisen ominaisuutta. Uusi säkeistö lähtee sen jälkeen, kun laulaja on jälleen täyttänyt keuhkonsa ilmalla. Tärkeintä tässä on se, että rytmikaavaan tarvitaan merkki osoittamaan se, että säkeistön loppua voi muunnella. Toisin sanoen merkin tehtävänä on osoittaa rytmisen variaation mahdollinen paikka rytmikaavassa.

Edellisistä nuottiesimerkeistä on hyvin näkynyt se, kuinka variaatio kohdistuu viimeiseen nuottiin ja tavuun. Merkitsen tätä jatkossa merkillä $+>>$. Merkki ilmoittaa sen, että säkeistön lopussa on painollinen tavu, jonka pituutta voidaan esityksessä muunnella vapaasti. Siirrän jälleen merkin rytmikaavaan, josta muodostuu nyt seuraavanlainen:

I-säe

$+-+-+-+(-)$

III-säe

$+-+-+-+(-)$
II-säe

$+-+-+(-)+\varnothing$

IV-säe

$+-+-+(-)+>>$ 


\section{Mitan toteutus erilaisilla rytmeillä ja nuottien kestoilla}

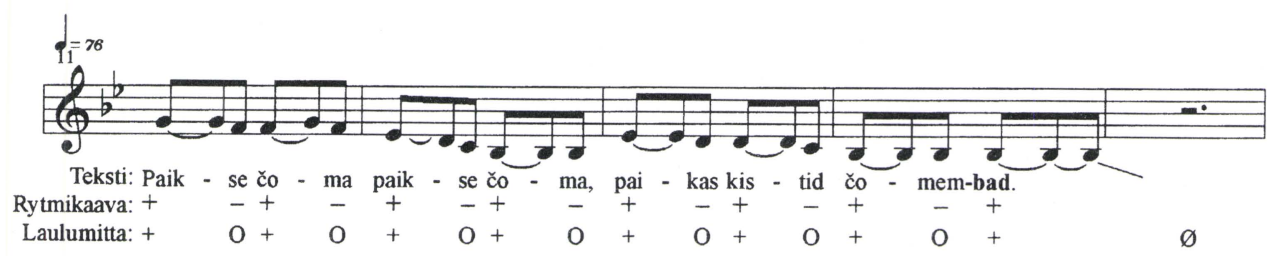

ESIMERKKI 5. Työlaulu tai heinänkorjuulaulu Vilhalan kylästä. (Eerola: Vilhala8/2000MD1/1).

Esimerkissä 5 (vrt. esimerkki 4) näkyy tauon paikka laulumitassa ja sen kesto. Melodia on nyt jakautunut niin, että painollinen isku saa pituudekseen kaksi 1/8-nuottia ja painoton yhden 1/8-nuotin. Tauko voidaan tulkita joko kokotauoksi tai joskus niin, että se on kokotauko lisättynä 1/8-nuotilla. Esimerkki osoittaa myös sen, kuinka mitta säilyy vaikka sitä toteutetaan eri rytmissä ja erilaisilla tavujen kestoilla.

Lähes samanlaisen laulun (esimerkki 6) esitti Antonina Bogdanova elokuussa 2002 Haragl-nimisessä kylässä. Rytmi on sama ja mitan toteutus tapahtuu lähes samalla tavalla $(1 / 4+1 / 8)$, mutta tauot eli metriset tyhjiöt ovat poissa. Laulun merkinnässä niitä ei ainakaan välttämättä tarvita. Toisaalta tauot on mahdollista sijoittaa sisäänhengityspaikkojen kohdille eli säkeiden alkuun. Tämä tarkoittaa käytännössä merkitsemistä ensimmäisen säeparin lopussa olevan 1/8-nuotin kohdalle. Tähän kohtaan olen myös sijoittanut metrisen tyhjiön $\varnothing$-merkin. Olen selvyyden vuoksi jättänyt kuvasta rytmikaavan pois. Lisäksi olen jättänyt alun melodian eli ensimmäisen säkeistön analysoimatta, koska näin kirjoitetun nuotin tulkintamahdollisuudet tulevat esiin. Esimerkin säkeistöjen väli oli hyvin vapaa, sitä vastoin säeparit laulaja esitti tiukasti yhdessä lähes nuotin mukaisesti. Olen jättänyt myös säkeistöjen lopusta tahtiviivat pois, kuvatakseni viimeisen nuotin epämääräistä kestoa. Tähän kohtaan olen sijoittanut $+>>$ merkin kuvaamaan säkeistön lopun variaation mahdollisuutta.
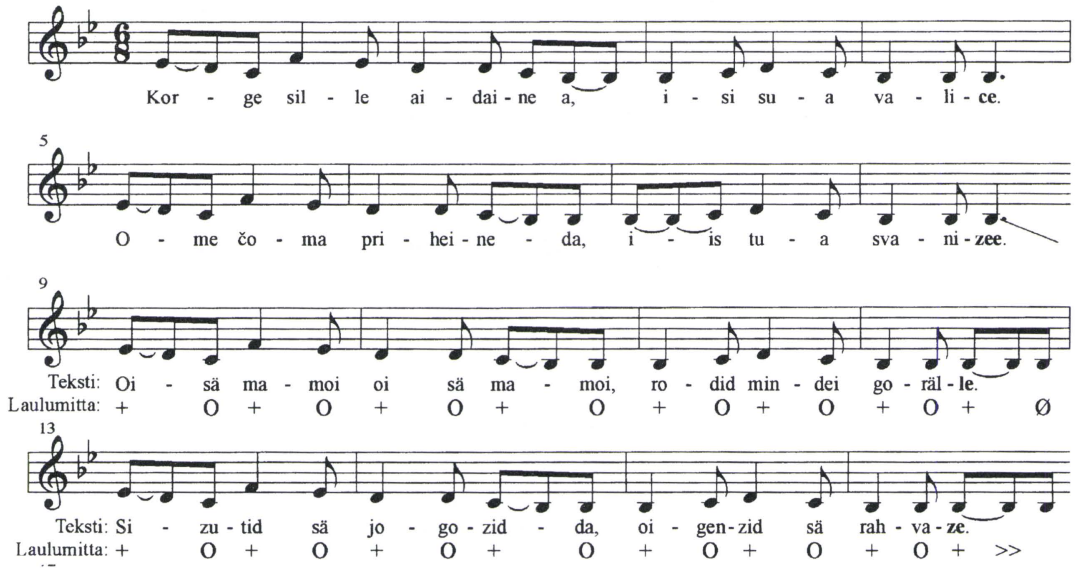

ESIMERKKI 6. Työlaulu Haragln kylästä. (Eerola: Harag19/2002Dat1(a)34Työla.) 
Esimerkki 7 kuvaa lähes samanlaista tilannetta. Rytmi on nyt vaihtunut $4 / 4+5 / 4$ rytmiksi. Teksti on lähes sama lukuunottamatta pientä koristelua sanassa rodid, jonka laulaja esittää roditi. Laulussa oleva 5/4-rytmi on hyvin tulkinnallinen ja se on hyvinkin voinut syntyä esittäjälle vahingossa. Monet niistä laulajista, joiden lauluja olen äänittänyt, ovat usein oikaisseet mahdollisen taljankan soittaman välisoiton. Tämä on usein selvinnyt vasta lopuksi, kun laulajat ovat huomauttaneet, että "taljankan (haitari) soittajaa ei ole nyt paikalla". Monet laulajista ovat pitäneet taukoja säkeistöjen välissä. Tauko on ollut yleensä esimerkiksi melodian mittainen tai puolet siitä. Tauon aikana laulajat ovat yleensä osoittaneet olevansa melko jännittyneitä äänitystilanteessa esimerkiksi nyökyttämällä päätään merkiksi siitä, että jotain tapahtuu myös tässä kohtaa. Metrisen analyysin kautta voidaan 5/4-rytmi helposti tulkita 4/4- ja 2/4-tahdiksi, josta laulaja on jättänyt yhden 1/4-nuotin jännittäessään pois. Pidän tätä hyvin todennäköisenä, sillä on mahdollista, että laulu on työlaulu, jossa ei ole alun perin ollut säestystä. Työlauluun viittaa myös hidas tempo. Toisaalta laulu noudattaa mitallista toteutusta, vaikka esitys eroaa muista aikaisemmista esimerkeistä poikkeuksellisella rytmityksellä. Lisäksi esitys ei ole aivan tyylinormien mukainen, sillä tästä säkeistöstä puuttuu riimitys kokonaan.

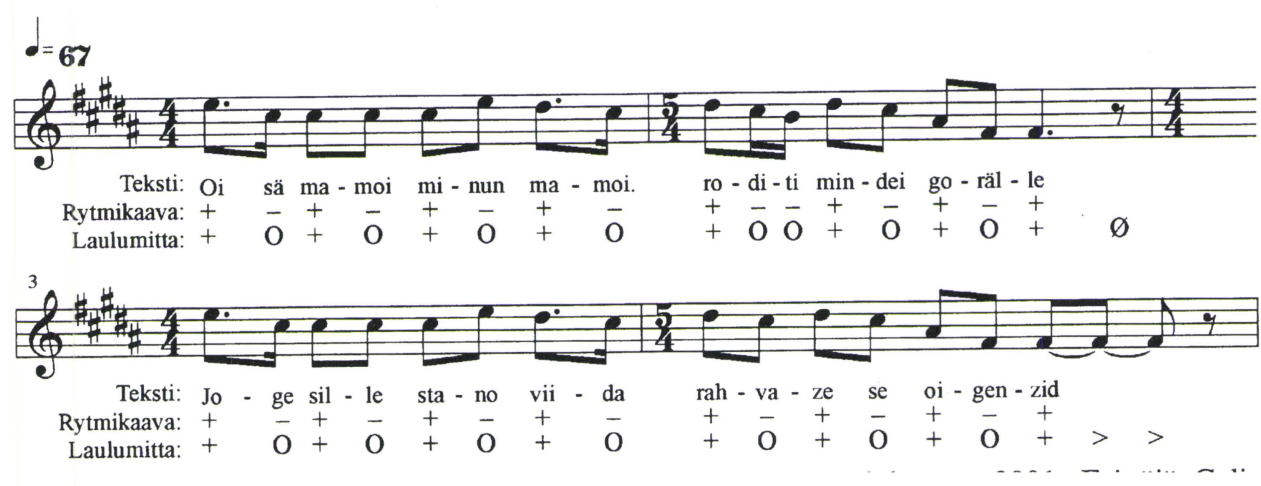

ESIMERKKI 7. Työlaulu tai lyhyt pajo Nemzan kylästä, äänitetty elokuussa 2001. Esittäjä Galina Lokina, joka kertoi motiivin olevan vanha kylän aihe. (Eerola: Nemza8/2001CD5b/76)

Esimerkin nuotintamista vaikeutti se, että laulaja osaltaan venytti säeparin ensimmäistä säveltä epämääräisesti. Tätä hankaloitti myös hänen tapansa laulaa I ja III säe niin, että niiden dynamiikka kasvoi vähitellen loppua kohden. Laulaja oli esimerkkeinä käyttämistäni laulajista nuorin ja oli selvästi kuunnellut tai opiskellut klassista musiikkia. Muuten kappaleen nuotintaminen ei tuottanut mahdottomia ongelmia.

Tyylinormi rikkoutuu esimerkissä lähinnä siitä syystä, että sanat ovat IV säkeessä vaihtaneet järjestystä. Esimerkissä 6 IV säkeistö kuului: oigenzid sä rahvaze. Tällöin riimitys säilyi. Esimerkissä 7 IV säkeistössä järjestys on: rahvaze se oigenzid, jolloin riimiä ei synny. 


\section{Lopuksi}

Esimerkit ovat osoittaneet, että vaikka laulut noudattavat lähtöoletuksena valitsemaani mittaa, mitan merkintä kaipaa täydennyksiä, jotta sillä voisi kuvata lyhyiden pajojen taustalla vallitsevaa rytmistä kaavaa eli rytmipakkoa (ks. Leino 1982: 44-45) ja että se ottaisi huomioon myös tyylinormit. Pajojen metrinen tulkinta ja merkintä tyylinormeja huomioimalla edellytti tiettyjä sääntöjä tulkintojen ehdoiksi. Ilman näitä sääntöjä metrinen tulkinta johtaa monenlaisiin malleihin ja ratkaisuihin ${ }^{19}$. Sääntöjen tehtävänä on karsia analyysissä olevien vaihtoehtojen määrää. Tämä on osaltaan ollut mahdollista sen takia, että aineisto on ollut hyvin tasalaatuista - mikä puolestaan on mielestäni tärkeä lähtökohta rytmikaava- tai metriikka-analyysiä tehtäessä. Jos aineisto on laadultaan epätasaista, on vaikea lähteä selvittämään laulujen rakenteita, koska ei ole olemassa vertailukohtia. Niin ikään käyttämissäni lähteissä olevien säkeistöjen rakenteet ovat olleet lähes poikkeuksetta ABAB; Loninin (2000) kokoamista 349 pajosta vain 6 ei noudattanut tätä kaavaa. Myös Kettusen ja Siron (1935) vepsän kielen näytteiden seassa olleiden 46 pajon joukossa oli vain yksi poikkeus. Omissa äänitteissäni ei ole kuin muutama esimerkki säkeistön rakenteen rikkomisesta. Nämäkin ovat saattaneet syntyä vahingossa, koska yleensä näissä tapauksissa laulajilla on ongelmia muistaa sanoja, varsinkin vepsänkielisiä.

Työtäni voidaan tietyssä mielessä vielä pitää johdantona aiheeseen, enkä usko, että sääntöni ja menetelmäni olisivat virheettömät. Toisaalta kuvausta voi vielä tarkentaa esimerkiksi metrisen fonologian keinoin, joka voisi kuvata tarkemmin sitä, mitkä tavut osuvat mihinkin kohtaan ja miksi. En myöskään ole testannut sääntöjen tulkinnallisuutta ulkopuolisilla.

Listaan seuraavaksi määrittelemäni lyhyiden pajojen metriseen analysiin liittyvät säännöt:

1. Kaksitavuisten sanojen painot jaetaan +- . Jos säkeessä kuitenkin on vain kolme kaksitavuista sanaa, jaetaan viimeinen sana niin, että sen kummatkin tavut osuvat painollisille iskuille. Myös viidennen säännön riimiehdon on toteuduttava. Tällöin käytetään vaihtoehdon sallivaa merkkiä (-).

2. Jos säe alkaa kolmitavuisella sanalla, asettaa sanan perässä oleva täydentävä lisäsana kolmitavuisen viimeiselle tavulle painon. Tällöin täydentävä sana osuu painottomalle jalalle. Lisäsanoina voivat olla pronominit tai erilaiset $(v u, d a, a, i, s e)$ tavut.

3. Nelitavuiset sanat tulkitaan kuten kaksi kaksitavuista sanaa. Tällöin ne merkitään aina +-+- .

4. Jos II ja IV säkeen viimeinen sana on kolmitavuinen, kolmitavuisen sanan viimeinen tavu saa painon. Tätä seikkaa voimistaa se, jos kolmas tavu on riimissä edeltävän säeparin kanssa. Tässä on ajateltava myös säännön viisi riimiehtoa.

5. Jos riimit (loppusointu) sijaitsevat II ja IV säkeissä, painot jaetaan näissä säkeissä siten, että riiminä oleva tavu saa painon. 
Esimerkkien pohjalta mitasta puuttuivat tauot ja variaatioiden mahdollisuudet. Kokoan vielä tähän käyttämäni merkit ja niiden merkitykset:

$+=$ Painollinen tavu.

$-=$ Painoton tavu.

$(-)=$ Painoton tavu, joka voidaan joskus jättää pois. Tämän merkin paikalle osuva tavu voidaan siirtää sen jäljessä tulevan +-merkin kohdalle. Merkin paikalle voidaan sijoittaa myös anakruusi eli kohotavu, joka kuuluu seuraavaan säkeeseen.

$\varnothing=$ Ilmoittaa säännöllisesti esiintyvän tauon paikan mitassa. Mitallinen toteutus edellyttää, että tauko on aina saman mittainen ja että se on samassa paikassa. Tauolla on määrämitta, mutta se voi olla joka runossa eri pituinen.

$+>>=$ Ilmoittaa paikan, jossa painollisen tavun kestoa voidaan vapaasti varioida rikkomatta mittaa. Ilmoittaa lyhyissä pajoissa myös säkeistön lopun.

Näiden merkkien avulla on lyhyiden pajojen abstraktiksi rytmikaavaksi muodostunut:

I säe

$+-+-+-+(-)$

III säe

$+-+-+-+(-)$
II säe

$+-+-+(-)+\varnothing$

IV säe

$+-+-+(-)+>>$

Painolliset iskut (painollinen jalka) näyttävät olevan lyhyissä pajoissa hyvin hallitsevia (ks. Laitinen 2003: 227). Säkeistö päättyy ja alkaa painollisilla tavuilla. Myös riimit sijoitetaan mielellään painollisten tavujen kohdalle. Lisätavut ja vähemmän merkitykselliset (ei-leksikaaliset) tavut, jotka voidaan usein jättää pois sisällön muuttumatta, sijoitetaan painottomille iskuille. Myös esityksissä, joissa useampia kuulijoita on ollut läsnä, ovat nämä monesti yhtyneet painollisiin riimitavuihin. Tästä voidaan päätellä, että tietty poljento ja riimitykset yhdessä tekstin sisällön kanssa luovat lyhyiden pajojen ominaisluonteen. Poljento on tiukasti esittäjien mielessä ja tästä syystä sanoja jaetaan pääasiassa painollisten iskujen mukaan ja nähtävästi usein metriikan vastaisesti. Abstrakti rytmikaava asettaa tietyt ehdot, mutta ei identtisyyden vaatimusta. Kaava on automatisoiva ja näin se myös ohjaa etsimään keinoja automaattisuuden purkamiseksi (ks. Leino 1982: 316). Tämä selittää myös sitä, miksi joillakin esittäjillä on tarvetta muunnella säkeistöjen viimeistä tavua. Rytmikaava on hyvin optimoitu eikä siinä ole paljon muita kohtia, joissa variaatiota voisi käyttää rikkomatta mittaa. Rytmikaavassa olevat variaatiokohdat tarjoavat myös samalla esittäjälle mahdollisuuden persoonalliseen ja luovaan tulkintaan. Tätä voisi kuvata myös termillä "laulajan vapaus" (Laitinen 2003: 245), joka sallitaan kaavaa tai tyyliseikkoja rikkomatta tietyssä kohdassa laulua.

Tarkastelu osoittaa toisaalta sen, kuinka vahva metrinen malli taustalla on (ks. Carlson 2003: 4). Toisaalta näyttää myös siltä, että laulajilla on tarvetta noudattaa tyylinmukaista riimitystä keinoilla millä hyvänsä, jolloin mittaa joudutaan rikkomaan 
metriikan näkökulmasta. Tästä nousee esiin jälleen kysymys laulujen alkuperästä: onko laulut esitetty alunperin venäjänkielisinä, minkä jälkeen niihin on istutettu vepsänkielisiä tekstejä venäjänkielisen mallin mukaan. Tällöin on helposti saattanut syntyä mitanvastaisia säkeistöjä. Tämä ei riitä selittämään sitä, miksi monet runot näyttävät olevan mitanvastaisia. Mielestäni tässä on kyse mitan soveltamisesta, eikä niinkään rikkomisesta. Toisaalta kyse on myös kielen muuttumisesta ajan kuluessa (ks. Carlson 2003: 4).

Abstrakti rytmikaava on ikään kuin tietynlainen sekvenssi esittäjän mielessä (ks. Leino 1982: 88). Kun esittäjä aloittaa runon, astuu aikamuuttuja mukaan tapahtumaan. Sekvenssissä on tietyissä kohdin taukoja, painotuksia ja variaation sallivia paikkoja. Tällöin syntyy tarve jakaa mielessä olevat sanat siten, että sekvenssissä olevat tärkeät kohdat täyttyvät. Vähemmän merkityksellisiin kohtiin voidaan sijoittaa tavuja, joilla ei välttämättä ole muuta tehtävää kuin säilyttää laulajan mielessä ole rytmikaava. Vaikka aikamuuttuja tavallaan sekoittaa laulajaa luomaan näennäisesti mitanvastaisia säkeitä, paljastuu säkeiden taustalta kuitenkin se, kuinka tietty mitta säätelee rytmiä (ks. Leino 1982: 327).

\section{Viitteet}

1 Myös Venäjällä asuvien karjalaisten keskuudessa tšastuškoista käytetään nimitystä lyhytpajo (ks. Koski 1985: 2-7).

2 Venäläisten keskuudessa tšastuškoja on esitetty juhlatilaisuuksissa, joissa on esiintynyt morsianten katselua, piirileikkejä, tansseja ja pelejä. Yleensä näissä juhlissa oli tiukat pukeutumissäännöt.

3 Tšastuškoilla saatettiin myös julistaa omaa poliittista kantaa asioihin (ks. Čistov 1976: 204) tai tehdä pilkkaa poliittisista henkilöistä. Viime heinäkuussa (2003) tapasimme Päžjärvellä miehen, joka esitti (ilman melodiaa) meille kymmeniä sepittämiään säkeitä, joiden aiheina olivat Venäjän tämän hetken poliittiset tapahtumat ja henkilöt kuten esimerkiksi Putin.

${ }^{4}$ Esimerkkejä venäläisistä nimityksiä ovat $\mathrm{mm}$. pripevki, pribaski, taratorki, kachel'nžye, pokosnžye.

5 Keskustelin asiasta laulajan Galina Lokinan ja tulkkini Nikolai Fominin kanssa Nemzan kylässä elokuussa 2001 (Eerola: Nemza8/2001CD 5a).

6 Suomenruotsin sävelkulun (akuutti) arvellaan syntyneen suomenkielen vaikutuksesta (Lönnqvist 1981: 42). Itselleni on ollut usein vaikea kuunnella vepsän kieltä ehkä juuri siitä syystä, että monet puhuvat sitä kuin venäjän kieltä. Tätä voisi verrata myös tilanteeseen, jossa venäjänkielinen henkilö puhuu suomea. Sävelkulku on tällöin erilainen.

7 Tämä seikka osaltaan myös puoltaa sitä ajatusta, että laulut on tehty suoraan vepsänkielisinä eikä niitä ole käännetty venäjänkielisistä lauluista. Myös riimitykset puoltavat tätä, sillä harvoin missään kielessä riimit säilyvät, jos teksti käännetään suoraan kielestä toiseen.

8 Päžjärvellä (6/2003) kuulin ensi kertaa ns. karhunpeloitus-tšastuškasta. Naiset lauloivat tätä, kun leikkasivat sirpeillä viljaa. Vuoronperään yksi naisista nousi ylös ja lauloi kovalla äänellä säkeistön. Kun hän oli lopettanut, hänen takanaan tuleva alkoi laulaa. Tällainen tilanne, jossa on pakko alkaa laulaa silloin, kun vuoro osuu kohdalle, suosii improvisointikykyä. Miehet olivat yleensä kauempana pellon laidalla. Ehkä myös tästä syystä naisten piti laulaa kovaa, jotta miehet kuulisivat, että kaikki on hyvin.

9 Kettusen ja Siron suomennoksesta voidaan olla eri mieltä. Tätä seikkaa puoltaa se, että Kettunen $(1935$, III) itse huomauttaa teoksen alkulauseessa, että "suuressa kiireessämme jäi tarkistus tosin useasti varsin pinnalliseksi". Itse kääntäisin sanat hieman toisin: voika $=>$ itkee, kukku $=>$ kukkuu.

${ }^{10}$ Tämä ei välttämättä ole tapana joka kylässä, 
mutta mm. heinäkuussa 2003 Päžjärven kylässä sain demonstraation tilanteesta.

11 Olen kirjoittanut tämän hiukan eri tavalla kuin Kettusen ja Siron (1935) kirjassa, jossa kaikki näytteet on kirjoitettu foneettisilla merkeillä.

12 Leinon (1982: 51) tutkimus lähtee siitä, että on olemassa jokin mitta tai pohjakaava, jota tietynlaiset runot noudattavat. Tutkimukseensa hän on valinnut vain tämän tietyn mitan noudattavia runoja. Tutkimuksen peruskysymykset koskevatkin sitä, minkälaiset tavut voivat esiintyä tämän tietyn mitan nousuissa ja laskuissa ja mitä ehtoja riimiparin tulee täyttää jne. (Leino 1982: 58).

${ }^{13}$ Carlsonin (2003: 4) mukaan metri säilyy usein, vaikka äänteet muuttuvat tai putoavat pois. Metrinen asema vaikuttaa äänteenmuodostuksiin ja aiheuttaa sananmuodoissa variaatioita eli allomorfiaa.

${ }^{14}$ Vai onko ajatus, jonka mukaan säe kestää vain 4 painollista iskua, vain tutkijan laboratoriossaan kehittämä harha? Loogisesti ajatellen mikään ei estäisi säeparin tulkitsemista yhdeksi kahdeksanpainoiseksi kokonaisuudeksi.
${ }^{15}$ Kielen metriikka on hyvin pysyvä elementti. Kuten Carlson (2003: 4) kirjoittaa, "vaikka äänteet muuttuvat tai putoavat pois, metriikka säilyy". Tällöin on loogista ajatella, että vaikka vepsän kieli on saanut paljon vaikutteita venäjän kielestä, vepsän kansanrunouden metriset perusominaisuudet ovat säilyneet.

${ }^{16}$ Leino käyttää säkeen ja säeparin lopusta merkkejä + ja $\neq$.

${ }^{17}$ Leino esittelee myös muita mahdollisia termejä kuten metrinen aukko tai tauko.

${ }^{18}$ Useat naiset, jotka ovat pajoja esittäneet ovat pitäneet säkeistöjen välissä hyvin erilaisia taukoja, jopa säestyksen kanssa esiintyessään. Tähän sopii hyvin myös ajatus pajoista pieninä lauluina ilman juonellista yhteyttä. Tällöin säkeistöjä voi esittää irrallaan ns. pieninä lauluina. Myös Kurban kylässä naiset esittivät säkeistöjä vuoron perään välittämättä ajasta niiden välissä.

${ }^{19}$ Haluan vielä tässä tuodan esiin sen oletuksen, että metriikka on hyvin hallitseva seikka. Sen sanoja rajoittava ominaisuus saattaa jäädä vielä hallitsemaan kieltä vaikka kielen äänteet olisivat muuttuneet tai pudonneet pois (ks. Carlson 2003: 4).

\section{Lähteet}

Aristoteles (1997) Retoriikka - runousoppi. Helsinki: Gaudeamus.

Čistov K. V. (1976) "Kansanrunous". Venäläinen perinnekulttuuri-Neuvostoliiton PohjoisEuroopan venäläisväestön etnologiaa 1800-luvulta 1900-luvun alkuun. Toim. K. V. Čistov ja SNTL:n Tiedeakatemian N. N. Mikluho-Maklain nimelle omistetun Etnografian instituutin itäslaavilaisen jaoston työryhmä. Suomentanut Marjatta Ryynänen. Helsinki: SKS. Ss. 162-195.

Hakamies, Pekka (1994) "Vepsäläisten suullisesta perinteestä". Vepsäläiset - Vepsäläiset tutuiksi - Kirjoituksia vepsäläisten kulttuurista. Toim. Kaija Heikkinen ja Irma Mullonen. Karjalan tutkimuslaitoksen julkaisuja no 108. Joensuu: Joensuun yliopisto. Ss. 7386.

Hautala, Jouko (1955) "Käki tuo suven sanoman'. Muuttolintujen ym. pilauksesta”. Kalevalaseuran vuosikirja 35. Helsinki: WSOY. Ss. 123-148.

Karhu, Eino (2001) 'Tacituksen kynän arvoinen sankari”. Carelia 9/2001. http://carelia. onego.ru/2001-9/52.html (tarkistettu 28.1.2003).

Kettunen, Lauri \& Siro, Paavo (1935) Näytteitä vepsän murteista. Suomalais-ugrilaisen seuran toimituksia LXX. Helsinki: SKS:n kirjapainon oy.

Koski, Т. А. (1985) Карелские Частушки. Институт Языка, Литератури и Истори Карелсково Филиала Ан СССР. Петрозаводск.

Kotškurkina, Svetlana (1989) "Muinaisia kurgaaneja”. Punalippu 2/1989.

Kotškurkina, Svetlana (1994) "Vepsäläisten arkeologiasta ja vanhasta historiasta". Ison karhun jälkeläiset - perinne ja etninen identiteetti yhteiskunnallisessa murroksessa. SKS:n toimituksia 697. Toim. Pekka Hakamies. Helsinki: SKS. Ss. 41-50. 
Krogerus, Tellervo (1989) "Laulajan sanat: pohjoiskarjalaisia erityispiirteitä". Runon ja rajan teillä. Kalevalaseuran vuosikirja 68. Helsinki: SKS. Ss. 136-147.

Kupiainen, Unto (1974) Lyhyt runousoppi. Viidennen painoksen muuttamaton lisäpainos. Porvoo: WSOY

Kuusi, Matti (1963) "Varhaiskalavalainen runous". Suomen kirjallisuus I - Kirjoittamaton kirjallisuus. Toim. Matti Kuusi. Helsinki: SKS \& Otava. Ss. 129-215.

Laitinen, Heikki (2003) Matkoja musiikkiin 1800-luvun Suomessa. Acta Universitatis Tamperensis 943. Tampere: Tampereen yliopistopaino oy.

Leino, Pentti (1982) Kieli, runo ja mitta. Suomen kielen metriikka. SKS:n toimituksia 376. Helsinki: SKS.

Leisiö, Timo (1986) "Riimillisen kansanlaulun metriset systeemit. Aiheen alustavaa hahmottelua”. Etnomusikologian vuosikirja 1986. Toim. Vesa Kurkela \& Erkki Pekkilä. Helsinki: Suomen etnomusikologinen seura. Ss. 33-65.

Leisiö, Timo (2000) "Metri, rytmi, metrinen tyhjiö ja musiikillinen aika". Musiikin suunta 2/2000, ss. 14-24.

Lokki \& Palmgren (1995) Suomen linnut.

Lonin, Rürik (2000) Lühüdad pajoized. Petroskoi.

Lönnqvist, Bo (1981) Suomenruotsalaiset. Kansatieteellinen tutkielma kieliryhmästä. Jyväskylä: Gummerus.

Oksala, Yrjö (1980) Musiikin perusteet. II osa. Rytmioppi. Helsinki: Musiikki Fazer.

Pimenov, Vladimir \& Strogalštšikova, Zinaida (1994) "Vepsäläisten etnisen kehityksen ongelmista”. Vepsäläiset - Vepsäläiset tutuiksi - Kirjoituksia vepsäläisten kulttuurista. Toim. Kaija Heikkinen \& Irma Mullonen. Karjalan tutkimuslaitoksen julkaisuja no 108. Joensuu: Joensuun yliopisto. Ss. 19-40.

Petuhov, Anatoli (1995) "Vepsä - Vepsän jälkeläiset". Itämerensuomalaiset. Heimokansojen historiaa ja kohtaloita. Toim. Mauno Jokipii. Jyväskylä. Ss. 387-400.

Salve, Kristi (1998) "Vepsäläisten kansallisesta identiteetistä". Ison karhun jälkeläiset perinne ja etninen identiteetti yhteiskunnallisessa murroksessa. SKS:n toimituksia 697. Toim. Pekka Hakamies. Helsinki: SKS. Ss. 119-140.

Savolainen Mikko (1998) Vepsä-Vepsänmaa. Oulu.

Strogalštšikova, Zinaida (1999) "Suomalais-ugrilainen sanskriitti ja sitä puhuva kansa yhä elää". Carelia 10/1999, ss. 49-53.

Suomi, Kari (1988) Johdatusta fonologiaan. Logopedian ja fonetiikan laitoksen julkaisuja N:O 2. Oulu: Oulun yliopisto.

Vinokurova Irina (1998) "Äänisvepsäläisten kirkkopyhät: perinteet ja nykyaika". Ison karhun jälkeläiset - perinne ja etninen identiteetti yhteiskunnallisessa murroksessa. SKS:n toimituksia 697. Toim. Pekka Hakamies. Helsinki: SKS. Ss. 99-118.

Virtanen, Leea (1992) Kansanviisauden kirja. Porvoo: WSOY.

Zemtsovsky, Izaly (2001) "Chasastushki. Russian traditional music. Russian federation." The New Grove Dictionary of Music and Musicians 22. 2nd ed. Ed Stanley Sadie. London: Macmillan. Ss. 1-33.

\section{PAINAMATTOMAT LÄHTEET}

Carlson, Lauri (2003) Fonologian ja morfologian harjoituksia Ctl 104. http://www.ling. helsinki.fi/ carlson/ctl104fo.html (tarkistettu 17.1.2003). 
Novožilova, Elena (2001) Code-Switcing in Contemporary Vepsian Language. Linguistic perspective on endangered languages. A SKY symposium. Helsinki August 29 - September 1, 2001. http://www.ling.helsinki.fi.sky/endabs.htm\#novozhilova

Trubetskoj, N.S. (1987) "O metrike tšastuški". Versty II/1927. Izbrannyje trudy po filologii. Sost. V. A. Vinogradov \& V. P. Neroznak. Moskva: Progress. Ss. 371-390. Otsikoimattoman suomenkielisen käännöksen käsikirjoitus. 